\title{
Rhodium-catalyzed direct alkylation of benzylic amines using alkyl bromides
}

\author{
Martin Anschuber ${ }^{1} \cdot$ Robert Pollice $^{2} \cdot$ Michael Schnürch $^{1}$ (D)
}

Received: 29 August 2018 / Accepted: 25 September 2018 / Published online: 13 November 2018

(c) The Author(s) 2018

\begin{abstract}
Within this contribution, the development and substrate scope evaluation of a direct alkylation protocol of the $\mathrm{C}\left(\mathrm{sp}^{3}\right)-\mathrm{H}$ bond of benzylic amines using alkyl bromides is reported. This pyridine-directed method is initiated by elimination of the alkyl bromide to a terminal olefin, which is then the true alkylating agent.
\end{abstract}

\section{Graphical abstract}

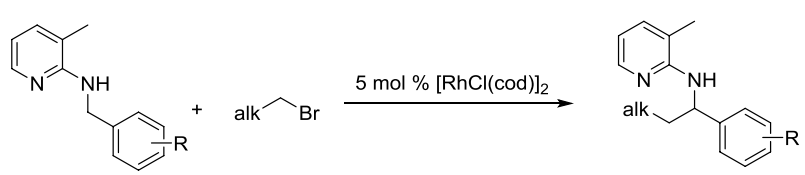

Keywords $\mathrm{C}-\mathrm{H}$ activation $\cdot \mathrm{C}-\mathrm{H}$ functionalization $\cdot$ Directing group $\cdot$ Catalysis

\section{Introduction}

Direct $\mathrm{C}-\mathrm{H}$ functionalization via metal catalysis is emerging as one of the most frequently investigated methods in recent years. This can be deduced from the large number of contributions published almost on a daily basis, and the number of review articles summarizing various aspects of the field [1-4]. The largest part of research is dedicated to functional group directed $\mathrm{C}-\mathrm{H}$ functionalization reactions. By now literally, all of the most frequently occurring functional groups have been used as a directing group, at least in a small set of examples [5, 6]. Regarding the transformations which have been reported, the variety has increased in recent years, as well. Besides arylation, alkylation, and alkenylation reactions, also more and more C-heteroatom bond forming reactions are disclosed. Regarding alkylation reactions, olefins

Michael Schnürch

michael.schnuerch@tuwien.ac.at

1 Institute of Applied Synthetic Chemistry, TU Wien, Getreidemarkt 9/163, 1060 Vienna, Austria

2 Laboratorium für Organische Chemie, ETH Zürich, Vladimir-Prelog-Weg 2, 8093 Zurich, Switzerland are the most frequently applied alkyl source [7]. However, it has to be mentioned that literature examples often limit themselves to functional group-substituted or long-chain alkenes to avoid working with gaseous reagents. We have shown, previously, that gaseous alkenes can be replaced by quaternary ammonium salts, which deliver olefins in-situ via Hofmann elimination (Scheme 1) [8].

This is a very convenient protocol, since all these salts are easy-to-handle solids. Even though the quaternary ammonium salts of interest are cheap reagents, the question was raised whether alkyl halides can be used as olefin replacement, as well, since ammonium salts are typically prepared from alkyl halides and ammonia. If so, for introduction of short alkyl chains gaseous reagents could be replaced by liquid ones, which would still be more convenient than using their gaseous counterparts. We have previously investigated such a transformation briefly, and found that the reaction actually proceeds via the initial elimination to the olefin, which is then the true alkylating agent [9]. However, we then focused on mechanistic investigations of the alkylation protocol using hex-1-ene and did not investigate the substrate scope of the alkyl bromide protocol [10].

In the literature, alkyl halides are known to be suitable alkyl sources for direct alkylation reactions; however, in 
Scheme 1<smiles>Cc1cccnc1NCc1ccccc1</smiles><smiles>[R]C[N+](C[R])(C[R])C[R]</smiles>
$[\mathrm{RhCl}(\mathrm{cod})]_{2}(5 \mathrm{~mol} \%)$ $\mathrm{KOH}$ (3 eq.)

toluene, $140{ }^{\circ} \mathrm{C}, \mathrm{Ar}$<smiles>[R]CC(Nc1ncccc1C)c1ccccc1</smiles>

$\mathrm{Ni}(\text { acac })_{2}$, dpppz, $\mathrm{Cs}_{2} \mathrm{CO}_{3}$, toluene, $\mathrm{N}_{2}, 150{ }^{\circ} \mathrm{C}$<smiles>[R3]CCCC([R])([R])C(=O)Nc1cccc2cccnc12</smiles>

Scheme 3

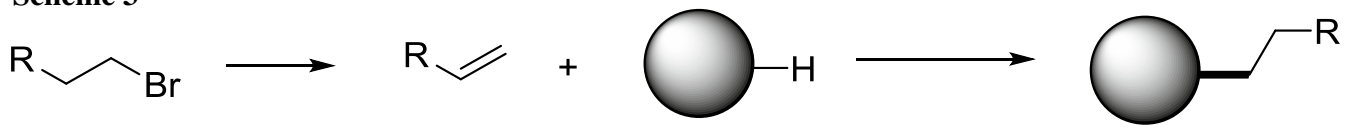

none of the examples, a prior elimination to an olefin is considered [11-16]. For most of them, such a mechanistic pathway can be excluded, since alkyl halide substrates which cannot give elimination to an olefin are amongst the reported examples (e.g., benzyl halides or iodomethane). However, among the reported examples, there is one contribution in which there is a high probability that initial elimination might precede the actual alkylation [17]. In this contribution, all alkyl halide examples allow the initial olefin formation, and additionally, shortcomings of the transformation could be explained, as well, since, e.g., benzylic and allylic halides failed to give the desired products (Scheme 2).

Within this contribution, we report on the development and substrate scope evaluation of an alkylation protocol using alkyl bromides initially eliminating to the corresponding terminal olefins before direct alkylation takes place (Scheme 3).

\section{Results and discussion}

Before turning towards the substrate scope evaluation, we wanted to revisit the reaction optimization briefly. We started using the reaction conditions of our previously reported $\mathrm{Rh}(\mathrm{I})$-catalyzed alkylation protocol [8] with $\mathbf{1}$ as substrate and 1-bromohexane instead of a quaternary ammonium salt, since these conditions were quite successful in Hofmann elimination. The first result was not very satisfactory, delivering only $12 \%$ yield of the desired product 6, showing that the conditions for the previous protocol could not be applied when alkyl halides are the alkyl source (Table 1, entry 1). Hence, further optimization was necessary. First, we did two experiments, once increasing and once decreasing the amount of $\mathrm{KOH}$. Decreasing the amount of the base to 0.5 equivalents had a detrimental effect and the yield was cut half to $6 \%$ (Table 1 , entry 2). Also the threefold amount of base led only to a slightly increased yield of $16 \%$ (Table 1 , entry 3 ). Next, the temperature was increased to $160{ }^{\circ} \mathrm{C}$. However, also in this case, the effect was not dramatic and $22 \%$ of $\mathbf{6}$ were obtained (Table 1 , entry 4 ). In a next step, we prolonged the reaction time, first to $46 \mathrm{~h}$, then to $70 \mathrm{~h}$. The resulting yields were $36 \%$ and $41 \%$, respectively.

The final step in the optimization was substituting $\mathrm{KOH}$ by $\mathrm{K}_{2} \mathrm{CO}_{3}$ and, at the same time, increasing the amount to 4.5 equivalents. The isolated yield of this reaction was $50 \%$. Unfortunately, all other optimization experiments did not lead to a higher yield. Compared to our previously published quaternary ammonium salt protocol, this corresponds to an about 10-20\% lower yield.

It has to be mentioned that this transformation is limited to the application of alkyl bromides, since alkyl chlorides did not react at all, and alkyl iodides give $N$-alkylation instead of the desired C-alkylation.

With the final conditions in hand, we started investigating the substrate scope with respect to alkyl bromides. First, we used different alkyl halides with a carbon chain length up to C22 (Scheme 4, products 2-14).

Bromoethane gave an isolated yield of only $25 \%$ of 2 . However, to synthesize $2, \mathrm{~N}\left(\mathrm{Et}_{4}\right) \mathrm{Br}$ can be used giving $68 \%$ yield [8]. Using longer alkyl bromides gave much better results, i.e., yields typically around 50\%. Especially, 
Table 1 Selected screening results for alkylation of 1 using $n$-hexyl bromide

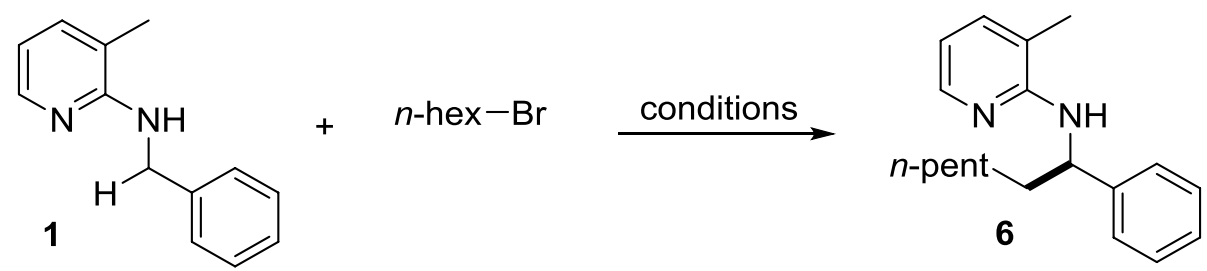

\begin{tabular}{|c|c|c|c|c|c|c|}
\hline Experiment & Base & Eq. base & Catalyst $/ 5 \mathrm{~mol} \%$ & Temperature $/{ }^{\circ} \mathrm{C}$ & Time/h & Yield/\% \\
\hline 1 & $\mathrm{KOH}$ & 1.0 & {$[\mathrm{RhCl}(\operatorname{cod})]_{2}$} & 140 & 22 & 12 \\
\hline 2 & $\mathrm{KOH}$ & 0.5 & {$[\mathrm{RhCl}(\operatorname{cod})]_{2}$} & 140 & 22 & 6 \\
\hline 3 & $\mathrm{KOH}$ & 3.0 & {$[\mathrm{RhCl}(\operatorname{cod})]_{2}$} & 140 & 22 & 16 \\
\hline 4 & $\mathrm{KOH}$ & 3.0 & {$[\mathrm{RhCl}(\operatorname{cod})]_{2}$} & 160 & 22 & 22 \\
\hline 5 & $\mathrm{KOH}$ & 3.0 & {$[\mathrm{RhCl}(\operatorname{cod})]_{2}$} & 160 & 46 & 36 \\
\hline 6 & $\mathrm{KOH}$ & 3.0 & {$[\mathrm{RhCl}(\operatorname{cod})]_{2}$} & 160 & 70 & 41 \\
\hline 7 & $\mathrm{~K}_{2} \mathrm{CO}_{3}$ & 4.5 & {$[\mathrm{RhCl}(\operatorname{cod})]_{2}$} & 160 & 22 & 50 \\
\hline
\end{tabular}

alkyl chains from $\mathrm{C} 3$ to $\mathrm{C} 6$ and $\mathrm{C} 10$ to $\mathrm{C} 12$ gave basically the same isolated yield, i.e., they were within experimental error (Scheme 4, compounds 3-6, 9-11, 50-60\%). Interestingly, 1-bromoheptyl and 1-bromooctyl gave a slightly lower yield (7, 38\% and $\mathbf{8}, 42 \%)$, the reason for that being currently unclear. To go to the extreme, we also tested 1-bromodocosane (C22, product $\mathbf{1 2}, 31 \%)$ and observed that an alkyl bromide with such a long alkyl chain is still a potential substrate for this kind of reaction delivering the final product in $31 \%$ yield.

In addition to linear primary bromoalkanes, other alkyl bromides were tested, as well. Secondary linear alkyl bromides such as 2-bromopropane and 2-bromobutane gave the same product as their primary isomers although in considerably lower yield. This is due to the fact that the initial elimination to the corresponding olefin in case of 2-bromopropane seems to be slower, and in case of 2-bromobutane, it can additionally deliver two different olefins, of which only the terminal one can react, but the internal one is the more stable one. Using cyclohexyl bromide as substrate which can only deliver an internal olefin, no conversion was detected at all.

The reaction with 1-bromo-3-methylbutane as branched alkyl bromide delivered the product $\mathbf{1 3}$ in quite good yield of 55\% (Scheme 4). In addition, the alkylation with 1-bromo-2-phenylethane, which delivers styrene upon elimination, worked with an acceptable yield of $\mathbf{1 4}$ (Scheme 3,43\%). These two substrates are not accessible for this reaction via quaternary ammonium salts.

Next, it was tested whether the developed alkylation protocol is limited to unsubstituted alkyl halides, since utility and acceptance of the protocol would depend largely on the possibility of general applicability. It was hypothesized that other alkylation reactions using olefins should be accessible to our protocol as long as the moieties of the substrates do not deactivate or destroy the catalyst. However, it turned out that alkyl bromides eliminating to substituted allylic and vinylic compounds were not tolerated giving either no or very low conversion (Scheme 5).

In cases where the formed olefin is further away from the functional group, the reaction worked again as demonstrated by the reaction of ethyl 4-bromobutanoate and ethyl 5-bromopentanoate, which delivered the respective products in 57\% and 35\% yield, respectively (Scheme 6, compounds 18 and 19).

Furthermore, we changed the substitution pattern at the ortho-, meta-, and para-position of the benzyl group of our starting material. Substrate $\mathbf{1 5}$ is bearing an $o$-methyl group, $\mathbf{1 6}$ is bearing an $m$-methoxy group, and $\mathbf{1 7}$ is bearing a $p$-trifluoromethyl group. The rationale behind using these groups is to find out whether the reaction is influenced by sterically demanding groups, as well as both electron donating and withdrawing groups.

These substrates were tested in $n$-butylation and $n$-decylation reactions, respectively, to demonstrate the utility of our protocol to introduce both a short and a long alkyl chain. As can be seen in Scheme 6 (compounds 20-25), again, the same range of yields was obtained (47-62\%), apart from one reaction (vide infra). It was observed that the methyl group at the benzylic orthoposition decreased the yield compared to the unsubstituted starting compound $\mathbf{1}$ (Scheme 6, compounds $\mathbf{2 2}$ and 23). This can be rationalized using steric arguments. The decrease in yield is much more dramatic in case of 1-bromodecane as coupling partner as compared to 1-bromobutane, which again hints towards a steric effect. 


\section{Scheme 4}
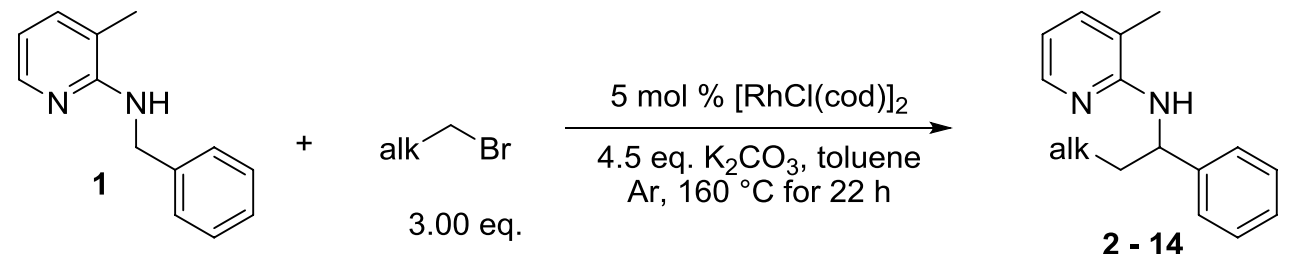<smiles>CCC(Nc1ncccc1C)c1ccccc1</smiles>

2, $25 \%$<smiles>COP(=O)(O)CCC(Nc1ncccc1C)c1ccccc1C(C)(F)F</smiles><smiles>[R][R]([Na])CCC(Nc1ncccc1C)c1ccccc1</smiles>

8, $42 \%$<smiles>Cc1cccnc1NC(CCC(=O)O)c1ccccc1</smiles><smiles>CCCC(Nc1ncccc1C)c1ccccc1</smiles>

3, $55 \%$<smiles>Cc1cccnc1NC(CCO)c1ccccc1</smiles>

4, $56 \%$

$32 \%$ using 2-bromopropane

$19 \%$ using 2-bromobutane<smiles>Cc1cccnc1NC(CCC(O)O)c1ccccc1OS(=O)(=O)O</smiles>

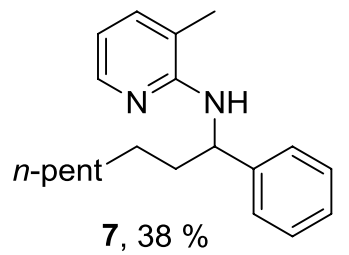<smiles>Cc1cccnc1NC(CCC(=O)O)c1ccccc1</smiles>

9, $56 \%$<smiles>Cc1cccnc1NC(CCOc1ccccc1)c1ccccc1</smiles>

$10,60 \%$<smiles>Cc1cccnc1NC(CC[Ge])c1ccccc1</smiles><smiles>Cc1cccnc1NC(CCC(C)C)c1ccccc1S(C)(=O)=O</smiles><smiles>Cc1cccnc1NC(CCc1ccccc1)c1ccccc1</smiles>

A $m$-methoxy group gave good yields of $56 \%$ in both cases (Scheme 6, compounds 20 and 21). In addition, an electron-withdrawing substituent such as a $p-\mathrm{CF}_{3}$ group seems to have no impact on the isolated yield, since $50 \%$ of $\mathbf{2 4}$ and $62 \%$ of $\mathbf{2 5}$ were obtained, respectively.
Finally, it has to be mentioned that the cleavage of the directing group is possible following a strategy that has proven to be successful in the literature [18] and in our lab [19-21]. 
Scheme 5<smiles>Cc1cccnc1NC(c1ccccc1)c1ncccc1C</smiles>

\section{Scheme 6}

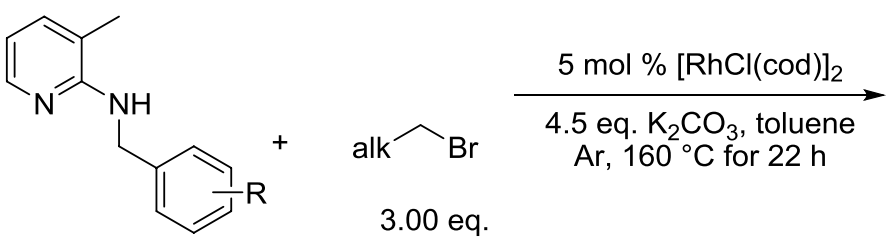

15: $\mathrm{R}=\mathrm{CH}_{3}$

16: $\mathrm{R}=\mathrm{OCH}_{3}$

17: $\mathrm{R}=\mathrm{CF}_{3}$<smiles>CCOC(=O)CCCC(Nc1ncccc1C)c1ccccc1</smiles>

$18,57 \%$<smiles>COc1cccc(C(CCC(=O)O)Nc2ncccc2C)c1</smiles>

21, $56 \%$<smiles>CCOC(=O)CCCCC(Nc1ncccc1C)c1ccccc1</smiles>

$19,35 \%$<smiles>[R][R]1ccc(C(CCl)Nc2ncccc2C)cc1</smiles><smiles>COc1cccc(C(CCc2ccccc2)Nc2ncccc2C)c1</smiles>

$20,56 \%$<smiles>Cc1ccccc1C(CCc1ccccc1)Nc1ncccc1C</smiles>

22, $47 \%$<smiles>Cc1ccccc1C(CCCl)Nc1ncccc1C</smiles>

23, $25 \%$<smiles>Cc1cccnc1NC(CCO)c1ccc(C(F)(F)F)cc1</smiles>

24, $50 \%$<smiles>Cc1cccnc1NC(CCC(=O)O)c1ccc(C(F)(F)F)cc1</smiles>

$25,62 \%$

\section{Conclusion}

We demonstrated that alkyl bromides can be used as olefin precursors in the direct alkylation of $\mathrm{C}\left(\mathrm{sp}^{3}\right)-\mathrm{H}$ bonds of benzylic amines. The reaction works with slightly lower efficiency as the previously disclosed protocol using quaternary ammonium salts [8]. Linear and unsubstituted alkyl bromides give the best results and examples up to a C22 chain length were reported. Functional group tolerance on the amine substrate was good, but limitations were observed when substituted alkyl bromides were used. If elimination to an allylic or vinylic olefin would need to 


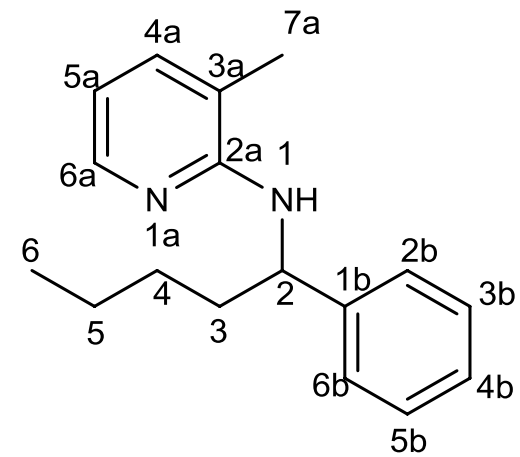

Fig. 1 Scheme for assigning NMR signals

occur, the reaction is inefficient. In addition, not many functional groups were tolerated. However, carboxylic acid esters work well. This gives a handle for further elaboration of the obtained products. Finally, cleavage of the directing group is possible, as well, an important feature in DG-assisted C-H functionalization.

\section{Experimental}

In general, unless noted otherwise, chemicals were purchased from commercial suppliers and used without further purification. Cyclooctadiene rhodium chloride dimer $[\mathrm{RhCl}(\mathrm{cod})]_{2}$ was handled in the glovebox under argon. Dry and degassed toluene was stored over molecular sieves in the glovebox under argon. Other dry solvents were obtained by passing pre-dried material through a cartridge-containing activated alumina (solvent dispensing system) and stored under nitrogen atmosphere until usage.

${ }^{1} \mathrm{H}$ NMR, ${ }^{13} \mathrm{C}$ NMR, and HSQC spectra were recorded on a Bruker Avance 400; chemical shifts are reported in ppm, using $\mathrm{Me}_{4} \mathrm{Si}$ as internal standard. NMR signals were assigned according to Fig. 1. GC-MS was performed on a Thermo Trace 1300 GC/MS ISQ LT (quadrupole, EI+) with a TR-5 capillary column $(7 \mathrm{~m} \times 0.32 \mathrm{~mm}, 0.25 \mu \mathrm{m}$ film, achiral). Temperature program: Start at $100{ }^{\circ} \mathrm{C}$ (hold $2 \mathrm{~min}$ ), $35^{\circ} \mathrm{C} / \mathrm{min}$, and $300{ }^{\circ} \mathrm{C}$ (hold $4 \mathrm{~min}$ ). GC spectra were recorded on a Thermo Focus GC using a BGB-5 capillary column $(30 \mathrm{~m} \times 0.32 \mathrm{~mm}, 1.0 \mu \mathrm{m}$ film, achiral $)$ with the following oven temperature program: Start at $100{ }^{\circ} \mathrm{C}$ (hold $2 \mathrm{~min}$ ), $35^{\circ} \mathrm{C} / \mathrm{min}, 300{ }^{\circ} \mathrm{C}$ (hold $4 \mathrm{~min}$ ). For TLC aluminum, backed silica gel 60 with fluorescence indicator F254 was used. Column chromatography was performed on Silica 60 from Merck (40-63 $\mu \mathrm{m})$. Flash chromatography was carried out on a Büchi Sepacore ${ }^{\text {TM }}$ MPLC system. Melting points were determined on an automated melting point system (Büchi Melting Point B-545). High-resolution mass spectrometry (HRMS) for the literature-unknown compounds was performed by liquid chromatography in combination with hybrid ion trap and high-resolution time-of-flight-mass spectrometry (LC-IT-TOF-MS) in only positive-ion detection mode with the recording of standard (MS) and tandem (MS/MS) spectra.

\section{General procedure $A$ for $\mathrm{C}-\mathrm{H}$ activation reactions to compounds 2-14 and 18-25}

Solid starting materials (except the catalyst) were placed in an oven-dried $8 \mathrm{~cm}^{3}$ glass vial with a solid top screw cap and a magnetic stirring bar. The vial was transferred into the glovebox under argon. Catalyst, liquid starting materials, solvent, and dodecane (as internal standard) were added in the glovebox. Finally, the vial was closed and the reaction mixture was heated in a heating block for the desired time at the desired temperature.

\section{General work-up procedure B for C-H activation reactions towards compounds 2-14 and 18-25}

After cooling the reaction mixture to room temperature, the solid material was removed by filtration using a Pasteur pipette with cotton and Hyflo. The residue was washed with $\mathrm{CH}_{2} \mathrm{Cl}_{2}$. The combined organic filtrate was concentrated under reduced pressure. The resulting crude residue was purified by flash column chromatography (LP/EtOAc).

\section{General procedure $\mathrm{C}$ for precursor synthesis (1, 15-17)}

Solid starting materials were placed in a $100 \mathrm{~cm}^{3} 3$-neckedflask, evacuated, and flushed with argon three times. Then, the liquid starting materials and, finally, toluene were added through the septum with a syringe. The mixture was heated at $130{ }^{\circ} \mathrm{C}$ (oil bath temperature) maintaining the argon atmosphere with a balloon. The reaction was stopped after $18 \mathrm{~h}$ (TLC). After cooling to r.t., the solid material was removed by filtration and washed with $\mathrm{CH}_{2} \mathrm{Cl}_{2}$. The combined organic layers were evaporated and the resulting crude product was purified by flash column chromatography (LP/ EtOAc) starting with 5\% EtOAc to $10 \%$ EtOAc over the course of $20 \mathrm{~min}$. Then, flash column chromatography was continued with 10\% EtOAc. Drying under reduced pressure delivered the pure product.

N-Benzyl-3-methylpyridin-2-amine (1) In a $100 \mathrm{~cm}^{3}$ threenecked-flask, were placed $67 \mathrm{mg} \mathrm{Pd}(\mathrm{OAc})_{2}(0.3 \mathrm{mmol}$, 0.02 eq.), $187 \mathrm{mg}$ rac. $\operatorname{BINAP}(0.3 \mathrm{mmol}, 0.02$ eq. $)$, and $7.214 \mathrm{~g} \mathrm{~K}_{2} \mathrm{CO}_{3}$ (52.5 mmol, 3.5 eq.), and the flask was evacuated and flushed with argon three times. Then, $1.63 \mathrm{~cm}^{3}$ 2-chloro-3-methylpyridine (15 mmol, 1 eq.), $1.97 \mathrm{~cm}^{3}$ freshly distilled benzylamine (18 mmol, 1.2 eq.), and, finally, $38 \mathrm{~cm}^{3}$ toluene were added through the septum with 
a syringe. The mixture was heated to $130{ }^{\circ} \mathrm{C}$ maintaining the argon atmosphere with a balloon. The reaction was stopped after $18 \mathrm{~h}$ (TLC). After cooling to r.t. the solid material was removed by filtration and washed with $150 \mathrm{~cm}^{3} \mathrm{CH}_{2} \mathrm{Cl}_{2}$. The combined organic layers were evaporated and the resulting crude product was purified by flash column chromatography (LP/EtOAc) starting with 5\% EtOAc to 10\% EtOAc over the course of $20 \mathrm{~min}$. Then, flash column chromatography was continued with $10 \%$ EtOAc. Drying under reduced pressure delivered $2.55 \mathrm{~g}(86 \%) \mathbf{1}$ as beige solid. Analytical data are in accordance to the literature [22].

3-Methyl-N-(1-phenylpropyl)pyridin-2-amine (2) The reaction was carried out according to general procedure $\mathrm{A}$ with $100 \mathrm{mg} 1$ ( $0.50 \mathrm{mmol}, 1$ eq.), $163 \mathrm{mg}$ 1-bromoethane (1.50 mmol, 3 eq.), $311 \mathrm{mg} \mathrm{K}_{2} \mathrm{CO}_{3}(2.25 \mathrm{mmol}, 4.5$ eq.), and $12 \mathrm{mg}[\mathrm{RhCl}(\mathrm{cod})]_{2}(0.025 \mathrm{mmol}, 0.05$ eq. $)$ in $2 \mathrm{~cm}^{3}$ dry and degassed toluene. The reaction mixture was heated for $22 \mathrm{~h}$ at $160{ }^{\circ} \mathrm{C}$. The general work-up procedure $\mathrm{B}$ for $\mathrm{C}-\mathrm{H}$ activation reactions was followed. The combined organic layers were evaporated and the resulting crude product was purified by flash column chromatography (LP/EtOAc, $45 \mathrm{~g} \mathrm{SiO}_{2}$, flowrate $30 \mathrm{~cm}^{3} / \mathrm{min}$ ) starting with pure LP for $10 \mathrm{~min}$ and then continuing using a gradient which varies the solvents from $0 \%$ to $5 \%$ EtOAc within 45 min. The product was dried under reduced pressure and 2 was isolated in 25\% (29 mg) yield as yellow oil. Analytical data are in accordance to the literature [19].

3-Methyl-N-(1-phenylbutyl)pyridin-2-amine (3) The reaction was carried out according to general procedure A with $100 \mathrm{mg} 1$ ( $0.50 \mathrm{mmol}, 1 \mathrm{eq}$.), $184 \mathrm{mg}$ 2-bromopropane (1.50 mmol, 3 eq.), $311 \mathrm{mg} \mathrm{K} \mathrm{CO}_{3}(2.25 \mathrm{mmol}, 4.5$ eq.), and $12 \mathrm{mg}[\mathrm{RhCl}(\mathrm{cod})]_{2}(0.025 \mathrm{mmol}, 0.05$ eq. $)$ in $2 \mathrm{~cm}^{3}$ dry and degassed toluene. The reaction mixture was heated for $22 \mathrm{~h}$ at $160^{\circ} \mathrm{C}$. The general work-up procedure $\mathrm{B}$ for $\mathrm{C}-\mathrm{H}$ activation reactions was followed. The combined organic layers were evaporated and the resulting crude product was purified by flash column chromatography (LP/EtOAc, $45 \mathrm{~g}$ $\mathrm{SiO}_{2}$, flowrate $30 \mathrm{~cm}^{3} / \mathrm{min}$ ) using a gradient which varies the solvents from $0 \%$ to 5\% EtOAc within $45 \mathrm{~min}$. Drying under reduced pressure delivered 3 in $32 \%$ (39 $\mathrm{mg}$ ) yield. TLC: $R_{\mathrm{f}}=0.74$ (LP/EtOAc 10:1); analytical data are in accordance to the literature [8].

3-Methyl- $N$-(1-phenylpentyl)pyridin-2-amine (4) The reaction was carried out according to general procedure A with $100 \mathrm{mg} 1$ ( $0.50 \mathrm{mmol}, 1$ eq.), $206 \mathrm{mg}$ 1-bromobutane ( $1.50 \mathrm{mmol}, 3$ eq.), $311 \mathrm{mg} \mathrm{K}_{2} \mathrm{CO}_{3}$ ( $2.25 \mathrm{mmol}, 4.5$ eq.), and $12 \mathrm{mg}[\mathrm{RhCl}(\mathrm{cod})]_{2}\left(0.025 \mathrm{mmol}, 0.05\right.$ eq.) in $2 \mathrm{~cm}^{3}$ dry and degassed toluene. The reaction mixture was heated for $22 \mathrm{~h}$ at $160^{\circ} \mathrm{C}$. The general work-up procedure $\mathrm{B}$ for $\mathrm{C}-\mathrm{H}$ activation reactions was followed. The combined organic layers were evaporated and the resulting crude product was purified by flash column chromatography (LP/EtOAc, $45 \mathrm{~g}$ $\mathrm{SiO}_{2}$, flowrate $30 \mathrm{~cm}^{3} / \mathrm{min}$ ) using a gradient which varies the solvents from $0 \%$ to $5 \%$ EtOAc within $45 \mathrm{~min}$. The product was dried under reduced pressure and $\mathbf{4}$ was isolated in 56\% $(71 \mathrm{mg}$ ) yield as pale yellowish oil. Analytical data are in accordance to the literature [8].

3-Methyl- $N$-(1-phenylhexyl)pyridin-2-amine (5) The reaction was carried out according to general procedure $\mathrm{A}$ with $100 \mathrm{mg} 1$ ( $0.50 \mathrm{mmol}, 1$ eq.), $225 \mathrm{mg} 1$-bromopentane (1.50 mmol, 3 eq.), $311 \mathrm{mg} \mathrm{K}{ }_{2} \mathrm{CO}_{3}$ (2.25 mmol, 4.5 eq.), and $12 \mathrm{mg}$ [ RhCl(cod) $]_{2}(0.025 \mathrm{mmol}, 0.05$ eq. $)$ in $2 \mathrm{~cm}^{3}$ dry and degassed toluene. The reaction mixture was heated for $22 \mathrm{~h}$ at $160{ }^{\circ} \mathrm{C}$. The general work-up procedure $\mathrm{B}$ for $\mathrm{C}-\mathrm{H}$ activation reactions was followed. The combined organic layers were evaporated and the resulting crude product was purified by flash column chromatography (LP/EtOAc, $45 \mathrm{~g}$ $\mathrm{SiO}_{2}$, flowrate $30 \mathrm{~cm}^{3} / \mathrm{min}$ ) starting with pure LP for $10 \mathrm{~min}$. Then, the flash column chromatography was continued using a gradient which varies the solvents from $0 \%$ to $10 \% \mathrm{EtOAc}$ within $45 \mathrm{~min}$. The product was dried under reduced pressure and 5 was isolated in 35\% (46 mg) yield as pale yellowish oil. Analytical data are in accordance to the literature [8].

3-Methyl-N-(1-phenylheptyl)pyridin-2-amine (6) The reaction was carried out according to general procedure $\mathrm{A}$ with $100 \mathrm{mg} 1$ ( $0.50 \mathrm{mmol}, 1 \mathrm{eq}$.), $248 \mathrm{mg}$ 1-bromohexane (1.50 mmol, 3 eq.), $311 \mathrm{mg} \mathrm{K}_{2} \mathrm{CO}_{3}$ (2.25 mmol, 4.5 eq.), and $12 \mathrm{mg}[\mathrm{RhCl}(\mathrm{cod})]_{2}(0.025 \mathrm{mmol}, 0.05$ eq. $)$ in $2 \mathrm{~cm}^{3}$ dry and degassed toluene. The reaction mixture was heated for $22 \mathrm{~h}$ at $160{ }^{\circ} \mathrm{C}$. The general work-up procedure B for $\mathrm{C}-\mathrm{H}$ activation reactions was followed. The combined organic layers were evaporated and the resulting crude product was purified by flash column chromatography (LP/EtOAc, $45 \mathrm{~g}$ $\mathrm{SiO}_{2}$, flowrate $30 \mathrm{~cm}^{3} / \mathrm{min}$ ) starting with pure LP for $10 \mathrm{~min}$. Then, the flash column chromatography was continued using a gradient which varies the solvents from 0\% to 10\% EtOAc within $45 \mathrm{~min}$. The product was dried under reduced pressure and 6 was isolated in 40\% (56 mg) yield as pale yellowish oil. Analytical data are in accordance to the literature [8].

3-Methyl-N-(1-phenyloctyl)pyridin-2-amine $\left(7, \mathrm{C}_{20} \mathrm{H}_{28} \mathrm{~N}_{2}\right)$ The reaction was carried out according to general procedure $\mathrm{A}$ with $100 \mathrm{mg} 1$ ( $0.50 \mathrm{mmol}, 1$ eq.), $269 \mathrm{mg}$ 1-bromoheptane ( $1.50 \mathrm{mmol}, 3$ eq.), $311 \mathrm{mg} \mathrm{K} \mathrm{CO}_{3}$ (2.25 mmol, 4.5 eq.), and $12 \mathrm{mg}$ [ RhCl(cod) $]_{2}(0.025 \mathrm{mmol}, 0.05$ eq. $)$ in $2 \mathrm{~cm}^{3}$ dry and degassed toluene. The reaction mixture was heated for $22 \mathrm{~h}$ at $160{ }^{\circ} \mathrm{C}$. The general work-up procedure $\mathrm{B}$ for $\mathrm{C}-\mathrm{H}$ activation reactions was followed. The combined organic layers were evaporated and the resulting crude product was purified by flash column chromatography (LP/EtOAc, $45 \mathrm{~g}$ $\mathrm{SiO}_{2}$, flowrate $30 \mathrm{~cm}^{3} / \mathrm{min}$ ) starting with pure LP for $5 \mathrm{~min}$. 
Then, the flash column chromatography was continued using a gradient which varies the solvents from $0 \%$ to $5 \%$ EtOAc within $1 \mathrm{~h}$. Drying under reduced pressure delivered 7 in $38 \%$ (57 mg) yield as yellow oil. TLC: $R_{\mathrm{f}}=0.59$ (LP/EtOAc 10:1); ${ }^{1} \mathrm{H}$ NMR (400 MHz, $\left.\mathrm{CDCl}_{3}\right): \delta=0.86(\mathrm{t}, J=14.6,9.8 \mathrm{~Hz}$, $\left.3 \mathrm{H}, \mathrm{C}[9]-\mathrm{H}_{3}\right), 1.14-1.38\left(\mathrm{~m}, 10 \mathrm{H}, \mathrm{C}[4-8]-\mathrm{H}_{2}\right), 1.87$ (ddd, $J=22.3,9.6,6.8 \mathrm{~Hz}, 1 \mathrm{H}, \mathrm{C}[3]-\mathrm{H}), 2.12\left(\mathrm{~s}, 3 \mathrm{H}, \mathrm{C}[7 \mathrm{a}]-\mathrm{H}_{3}\right)$, 4.37 (d, J=7.6 Hz, 1H, N-H), 5.24 (d, J=7.3 Hz, 1H, C[2]H), $6.47(\mathrm{dd}, J=7.1,5.1 \mathrm{~Hz}, 1 \mathrm{H}, \mathrm{C}[5 \mathrm{a}]-\mathrm{H}), 7.15-7.25(\mathrm{~m}$, 2H, C[4a; 4b]-H), 7.27-7.41 (m, 4H, C[2b; 3b; 5b; 6b]-H), $7.95(\mathrm{dd}, J=5.0,1.8 \mathrm{~Hz}, 1 \mathrm{H}, \mathrm{C}[6 \mathrm{a}]-\mathrm{H}) \mathrm{ppm} ;{ }^{13} \mathrm{C} \mathrm{NMR}$ (101 $\mathrm{MHz}, \mathrm{CDCl}_{3}$ ): $\delta=14.1$ (q, C[9]), 17.1 (q, C[7a]), 22.7 $(\mathrm{t}, \mathrm{C}[8]), 26.4(\mathrm{t}, \mathrm{C}[7]), 29.2(\mathrm{t}, \mathrm{C}[6]), 29.6(\mathrm{t}, \mathrm{C}[5]), 31.8(\mathrm{t}$, $\mathrm{C}[4]), 37.6$ (t, C[3]), 54.6 (d, C[2]), 112.5 (d, C[5a]), 116.2 (s, C[3a]), 126.5 (d, C[2b; 6b]), 126.7 (d, C[4b]), 128.4 (d, C[3b; 5b]), 136.7 (d, C[4a]), 144.6 (s, C[1b]), 145.6, (d, C[6a]), 156.2 (s, C[2a]) ppm; GC-MS: retention time: 7.86 min; main fragments: $m / z(\%)=296\left(\mathrm{M}^{+}, 11\right), 211(19)$, 197 (100), 108 (22), 91 (21), 65 (11).

3-Methyl-N-(1-phenylnonyl)pyridin-2-amine (8) The reaction was carried out according to general procedure A with $100 \mathrm{mg} 1$ ( $0.50 \mathrm{mmol}, 1 \mathrm{eq}$ ), $290 \mathrm{mg}$ 1-bromooctane (1.50 mmol, 3 eq.), $311 \mathrm{mg} \mathrm{K}_{2} \mathrm{CO}_{3}$ (2.25 mmol, 4.5 eq.), and $12 \mathrm{mg}[\mathrm{RhCl}(\mathrm{cod})]_{2}(0.025 \mathrm{mmol}, 0.05$ eq. $)$ in $2 \mathrm{~cm}^{3}$ dry and degassed toluene. The reaction mixture was heated for $22 \mathrm{~h}$ at $160{ }^{\circ} \mathrm{C}$. The general work-up procedure $\mathrm{B}$ for $\mathrm{C}-\mathrm{H}$ activation reactions was followed starting with pure LP for $10 \mathrm{~min}$. Then, the flash column chromatography was continued using a gradient which varies the solvents from $0 \%$ to $5 \%$ EtOAc within $1 \mathrm{~h}$. Drying under reduced pressure delivered 8 in $42 \%$ (65 mg) yield as yellow oil. TLC: $R_{\mathrm{f}}=0.51$ (LP/EtOAc $10: 1)$; analytical data are in accordance to the literature [8].

3-Methyl-N-(1-phenylundecyl)pyridin-2-amine (9, $\mathrm{C}_{23} \mathrm{H}_{34} \mathrm{~N}_{2}$ ) The reaction was carried out according to general procedure A with $100 \mathrm{mg} 1$ (0.50 mmol, 1 eq.), $332 \mathrm{mg}$ 1-bromodecane (1.50 mmol, 3 eq.), $311 \mathrm{mg} \mathrm{K} \mathrm{CO}_{3}$ (2.25 mmol, 4.5 eq.), and $12 \mathrm{mg}[\mathrm{RhCl}(\mathrm{cod})]_{2}(0.025 \mathrm{mmol}$, 0.05 eq.) in $2 \mathrm{~cm}^{3}$ dry and degassed toluene. The reaction mixture was heated for $22 \mathrm{~h}$ at $160{ }^{\circ} \mathrm{C}$. The general workup procedure $\mathrm{B}$ for $\mathrm{C}-\mathrm{H}$ activation reactions was followed using a gradient which varies the solvents from $0 \%$ to $5 \%$ EtOAc within $1 \mathrm{~h}$. Drying under reduced pressure delivered 9 in $56 \%(65 \mathrm{mg})$ yield. TLC: $R_{\mathrm{f}}=0.57$ (LP/EtOAc 10:1); ${ }^{1} \mathrm{H} \mathrm{NMR}\left(400 \mathrm{MHz}, \mathrm{CDCl}_{3}\right): \delta=0.88(\mathrm{t}, J=6.8 \mathrm{~Hz}$, $\left.3 \mathrm{H}, \mathrm{C}[12]-\mathrm{H}_{3}\right), 1.10-1.48\left(\mathrm{~m}, 16 \mathrm{H}, \mathrm{C}[4-11]-\mathrm{H}_{2}\right), 1.77-$ $1.98\left(\mathrm{~m}, 2 \mathrm{H}, \mathrm{C}[3]-\mathrm{H}_{2}\right), 2.12\left(\mathrm{~s}, 3 \mathrm{H}, \mathrm{C}[7 \mathrm{a}]-\mathrm{H}_{3}\right), 4.37$ (d, $J=7.4 \mathrm{~Hz}, 1 \mathrm{H}, \mathrm{N}-\mathrm{H}), 5.24$ (q, J=7.1 Hz, 1H, C[2]-H), 6.47 $(\mathrm{dd}, J=7.1,5.0 \mathrm{~Hz}, 1 \mathrm{H}, \mathrm{C}[5 \mathrm{a}]-\mathrm{H}), 7.15-7.27(\mathrm{~m}, 2 \mathrm{H}, \mathrm{C}[4 \mathrm{a}$; 4b]-H), 7.27-7.44 (m, 4H, C[2b; 3b; 5b; 6b]-H), 7.96 (dd, $J=5.1,1.8 \mathrm{~Hz}, 1 \mathrm{H}, \mathrm{C}[6 \mathrm{a}]-\mathrm{H}) \mathrm{ppm} ;{ }^{13} \mathrm{C} \mathrm{NMR}(101 \mathrm{MHz}$, $\mathrm{CDCl}_{3}$ ): $\delta=14.1$ (q, C[12]), 17.1 (q, C[7a]), 22.7 (t, C[6]),
26.4 (t, C[7]), 29.3 (t, C[5]), 29.5 (t, C[8, 9]), 29.6 (t, C[4a; 4b]), 31.9 (t, C[11]), 37.6 (t, C[3]), 54.6 (d, C[2]), 112.5 (d, C[5a]), 116.1 (s, C[3a]), 126.5 (d, C[2b; 6b]), 126.7 (d, C [4b]), 128.1 (d, C[3b; 5b]), 136.8 (d, C[4a]), 144.6 (s, C[1b]), 145.8 (d, C[6a]), 156.2 (s, C[2a]) ppm; GC-MS: retention time: $8.73 \mathrm{~min}$; main fragments: $\mathrm{m} / \mathrm{z}(\%)=338$ $\left(\mathrm{M}^{+}, 8\right), 211$ (20), 197 (100), 108 (23), 91 (18), 65 (7).

3-Methyl-N-(1-phenyldodecyl)pyridin-2-amine (10, $\mathrm{C}_{24} \mathrm{H}_{36} \mathrm{~N}_{2}$ ) The reaction was carried out according to general procedure A with $100 \mathrm{mg} 1$ (0.50 mmol, 1 eq.), $353 \mathrm{mg}$ 1-bromoundecane (1.50 mmol, 3 eq.), $311 \mathrm{mg} \mathrm{K}_{2} \mathrm{CO}_{3}$ (2.25 mmol, 4.5 eq.), and $12 \mathrm{mg}[\mathrm{RhCl}(\mathrm{cod})]_{2}(0.025 \mathrm{mmol}$, 0.05 eq.) in $2 \mathrm{~cm}^{3}$ dry and degassed toluene. The reaction mixture was heated for $22 \mathrm{~h}$ at $160{ }^{\circ} \mathrm{C}$. The general workup procedure $\mathrm{B}$ for $\mathrm{C}-\mathrm{H}$ activation reactions was followed starting with pure LP for $10 \mathrm{~min}$. Then, the flash column chromatography was continued using a gradient which varies the solvents from $0 \%$ to $5 \%$ EtOAc within $1 \mathrm{~h}$. Drying under reduced pressure delivered 10 in $60 \%$ (106 mg) yield. TLC: $R_{\mathrm{f}}=0.55$ (LP/EtOAc 10:1); ${ }^{1} \mathrm{H}$ NMR $(400 \mathrm{MHz}$, $\left.\mathrm{CDCl}_{3}\right): \delta=0.93\left(\mathrm{~s}, 3 \mathrm{H}, \mathrm{C}[13]-\mathrm{H}_{3}\right), 1.28(\mathrm{~s}, 18 \mathrm{H}, \mathrm{C}[4-12]-$ $\left.\mathrm{H}_{2}\right), 1.81-2.03\left(\mathrm{~m}, 2 \mathrm{H}, \mathrm{C}[3]-\mathrm{H}_{2}\right), 2.15$ (s, 3H, C[7a]- $\left.\mathrm{H}_{3}\right)$, 4.43 (s, 1H, N-H), 5.30 (q, J=7.1 Hz, 1H, C[2]-H), 6.50 $(\mathrm{dd}, J=7.1,5.1 \mathrm{~Hz}, 1 \mathrm{H}, \mathrm{C}[5 \mathrm{a}]-\mathrm{H}), 7.19-7.30(\mathrm{~m}, 2 \mathrm{H}, \mathrm{C}[4 \mathrm{a}$; 4b]-H)), 7.30-7.45 (m, 4H, C[2b; 3b; 5b; 6b]-H), 8.00 (dd, $J=5.0,1.9 \mathrm{~Hz}, 1 \mathrm{H}, \mathrm{C}[6 \mathrm{a}]-\mathrm{H}) \mathrm{ppm} ;{ }^{13} \mathrm{C} \mathrm{NMR}(101 \mathrm{MHz}$, $\left.\mathrm{CDCl}_{3}\right): \delta=14.2(\mathrm{q}, \mathrm{C}[13]), 17.1(\mathrm{q}, \mathrm{C}[7 \mathrm{a}]), 29.6(\mathrm{t}, \mathrm{C}[5-$ 10]), 32.0 (t, C[11]), 37. 6 (t, C[3]), 54.7 (d, C[2]), 112.5 (d, C[5a]), 116.2 (s, C[3a]), 126.5 (d, C[2b; 6b]), 126.7 (d, $\mathrm{C}[4 \mathrm{~b}]), 128.4(\mathrm{~d}, \mathrm{C}[3 \mathrm{~b} ; 5 \mathrm{~b}]), 136.8(\mathrm{~d}, \mathrm{C}[4 \mathrm{a}]), 144.6(\mathrm{~s}$, C[1b]), 145.5 (d, C[6a]), 156.2 (s, C[2a]) ppm; GC-MS: retention time: $8.73 \mathrm{~min}$; main fragments: $\mathrm{m} / \mathrm{z}(\%)=352$ (M+, 8), 211 (19), 197 (100), 108 (23), 91 (19), 65 (7); HRMS: $m / z$ calculated for $\mathrm{C}_{24} \mathrm{H}_{36} \mathrm{~N}_{2}\left([\mathrm{M}+\mathrm{H}]^{+}\right)$353.2957, found $353.2972 ; \Delta=5.93 \mathrm{ppm}$.

3-Methyl-N-(1-phenyltridecyl)pyridin-2-amine (11, $\mathrm{C}_{25} \mathrm{H}_{38} \mathrm{~N}_{2}$ ) The reaction was carried out according to general procedure A with $100 \mathrm{mg} 1$ (0.50 mmol, 1 eq.), $374 \mathrm{mg}$ 1-bromododecane (1.50 mmol, 3 eq.), $311 \mathrm{mg}$ $\mathrm{K}_{2} \mathrm{CO}_{3}$ (2.25 mmol, 4.5 eq.), and $12 \mathrm{mg}[\mathrm{RhCl}(\mathrm{cod})]_{2}$ ( $0.025 \mathrm{mmol}, 0.05$ eq.) in $2 \mathrm{~cm}^{3}$ dry and degassed toluene. The reaction mixture was heated for $22 \mathrm{~h}$ at $160{ }^{\circ} \mathrm{C}$. The general work-up procedure $\mathrm{B}$ for $\mathrm{C}-\mathrm{H}$ activation reactions was followed using first 5 min pure LP and continuing using a gradient which varies the solvents from $0 \%$ to 5\% EtOAc within 1 h. Drying delivered 24 in 56\% (96 mg) yield as pale yellowish oil. TLC: $R_{\mathrm{f}}=0.9$ (LP/EtOAc 10:1); ${ }^{1} \mathrm{H} \mathrm{NMR}\left(400 \mathrm{MHz}, \mathrm{CDCl}_{3}\right): \delta=0.88(\mathrm{t}, J=6.8 \mathrm{~Hz}, 3 \mathrm{H}$, $\left.\mathrm{C}[14]-\mathrm{H}_{3}\right), 1.21-1.36\left(\mathrm{~m}, 20 \mathrm{H}, \mathrm{C}[4-13]-\mathrm{H}_{2}\right), 1.78-1.97(\mathrm{~m}$, $\left.2 \mathrm{H}, \mathrm{C}[3]-\mathrm{H}_{2}\right), 2.12\left(\mathrm{~s}, 3 \mathrm{H}, \mathrm{C}[7 \mathrm{a}]-\mathrm{H}_{3}\right), 4.41(\mathrm{~s}, 1 \mathrm{H}, \mathrm{N}-\mathrm{H})$, $5.26(\mathrm{q}, J=7.3 \mathrm{~Hz}, 1 \mathrm{H}, \mathrm{C}[2]-\mathrm{H}), 6.47(\mathrm{dd}, J=7.1,5.1 \mathrm{~Hz}$, 
1H, C-[5a]-H), 7.18-7.25 (m, 2H, C[4a; 4b]-H), 7.31 (t, $J=7.5 \mathrm{~Hz}, 2 \mathrm{H}, \mathrm{C}[2 \mathrm{~b} ; 6 \mathrm{~b}]-\mathrm{H}, 7.37$ (d, $J=7.5 \mathrm{~Hz}, 2 \mathrm{H}, \mathrm{C}[3 \mathrm{~b}$; $5 \mathrm{~b}]-\mathrm{H}), 7.95(\mathrm{dd}, J=5.1,1.7 \mathrm{~Hz}, 1 \mathrm{H}, \mathrm{C}[6 \mathrm{a}]-\mathrm{H}) \mathrm{ppm} ;{ }^{13} \mathrm{C}$ NMR (101 MHz, $\left.\mathrm{CDCl}_{3}\right): \delta=14.14$ (q, C[14]), 17.09 (q, C[7a]), 22.71 (t, C[13]), 26.35 (t, C[12]), 29.31-29.75 (m) (t, C[5-11]), 31.94 (t, C[4]), 37.55 (t, C[3]), 54.72 (d, C[2]), 112.50 (d C[5a]), 126.53 (d, C[3b; 5b]), 126.73 (d, C[4b]), 128.39 (d, C[2b; 6b]), 136.91 (d, C[4a]), 144.43 (s, C[1b]) ppm; GC-MS: retention time: $9.22 \mathrm{~min}$; main fragments: $\mathrm{m} / \mathrm{z}(\%)=366\left(\mathrm{M}^{+}, 8\right), 267$ (1), 211 (19), 197 (100), 108 (26), 91 (18), 65 (6); HRMS: $m / z$ calculated for $\mathrm{C}_{25} \mathrm{H}_{38} \mathrm{~N}_{2}$ $\left([\mathrm{M}+\mathrm{H}]^{+}\right) 367.3114$, found $367.3119 ; \Delta=3.14 \mathrm{ppm}$.

3-Methyl- $\mathrm{N}$-(1-phenyltricosyl)pyridin-2-amine (12, $\mathrm{C}_{35} \mathrm{H}_{58} \mathrm{~N}_{2}$ ) The reaction was carried out according to general procedure A with $100 \mathrm{mg} 1(0.50 \mathrm{mmol}, 1$ eq. $), 584 \mathrm{mg}$ 1-bromodocosane (1.50 mmol, 3 eq.), $311 \mathrm{mg} \mathrm{K}_{2} \mathrm{CO}_{3}$ ( $2.25 \mathrm{mmol}, 4.5$ eq.), and $12 \mathrm{mg}[\mathrm{RhCl}(\mathrm{cod})]_{2}(0.025 \mathrm{mmol}$, 0.05 eq.) in $2 \mathrm{~cm}^{3}$ dry and degassed toluene. The reaction mixture was heated for $22 \mathrm{~h}$ at $160^{\circ} \mathrm{C}$. The general work-up procedure $\mathrm{B}$ for $\mathrm{C}-\mathrm{H}$ activation reactions was followed using a gradient which varies the solvents from $0 \%$ to $20 \%$ EtOAc within $45 \mathrm{~min}$. Upon recrystallisation, the pure product was isolated in $31 \%$ ( $80 \mathrm{mg}$ ) yield as white crystals. M.p.: 47.5$47.6{ }^{\circ} \mathrm{C}$; TLC: $R_{\mathrm{f}}=0.8$ (LP/EtOAc 5:1); ${ }^{1} \mathrm{H}$ NMR $(400 \mathrm{MHz}$, $\left.\left.\mathrm{CDCl}_{3}\right): \delta=0.88\left(\mathrm{t}, J=6.7 \mathrm{~Hz}, 3 \mathrm{H}, \mathrm{C}[24]-\mathrm{H}_{3}\right),\right), 1.19-1.33$ (m, 40H, C[4-23]- $\left.\mathrm{H}_{2}\right), 1.80-1.90\left(\mathrm{~m}, 2 \mathrm{H}, \mathrm{C}[3]-\mathrm{H}_{2}\right), 2.13$ (s, 3H, C[7a]- $\left.\mathrm{H}_{3}\right), 4.52(\mathrm{~s}, 1 \mathrm{H}, \mathrm{N}-\mathrm{H}), 5.32(\mathrm{~s}, 1 \mathrm{H}, \mathrm{C}[2]-\mathrm{H})$, 6.49 (dd, $J=7.1,5.2 \mathrm{~Hz}, 1 \mathrm{H}, \mathrm{C}[5 \mathrm{a}]-\mathrm{H}), 7.18-7.25(\mathrm{~m}, 2 \mathrm{H}$, C[4a; 4b]-H), 7.31 (t, $J=7.5 \mathrm{~Hz}, 2 \mathrm{H}, \mathrm{C}[2 \mathrm{~b} ; 6 \mathrm{~b}]-\mathrm{H}), 7.39$ (d, $J=7.5 \mathrm{~Hz}, 2 \mathrm{H}, \mathrm{C}[3 \mathrm{~b} ; 5 \mathrm{~b}]-\mathrm{H}), 7.95(\mathrm{dd}, J=5.2,1.7 \mathrm{~Hz}$, $1 \mathrm{H}, \mathrm{C}[6 \mathrm{a}]-\mathrm{H}) \mathrm{ppm} ;{ }^{13} \mathrm{C} \mathrm{NMR}\left(101 \mathrm{MHz}, \mathrm{CDCl}_{3}\right): \delta=14.1$ (q, C[24]), 17.1 (q, C[7a]), 22.7 (t, C[23]), 26.3 (t, C[4]), 29.81-29.32 (m) (t, C[5-21]), 31.9 (t, C[22]), 37.6 (t, C[3]), $55.0(\mathrm{~d}, \mathrm{C}[2]), 112.5$ (d, C[5a]), 126.5 (d, C[3b; 5b]), 126.9 (d, C[4b]), 128.5 (d, C[2b; 6b]) ppm; LC-MS: retention time: $2.28 \mathrm{~min}$; main fragments: $\mathrm{m} / \mathrm{z}(\%)=507.40\left([\mathrm{M}+\mathrm{H}]^{+}\right.$, 100), 508.4 (40), 509.4 (7), 493.4 (18), 322.2 (16), 314.2 (10), $282.2(28)$.

3-Methyl-N-(4-methyl-1-phenylpentyl)pyridin-2-amine (13, $\mathrm{C}_{18} \mathrm{H}_{24} \mathrm{~N}_{2}$ ) The reaction was carried out according to general procedure A with $100 \mathrm{mg} 1$ ( $0.50 \mathrm{mmol}, 1 \mathrm{eq}$.), $227 \mathrm{mg}$ 1-bromo-3-methylbutane ( $1.50 \mathrm{mmol}, 3$ eq.), $311 \mathrm{mg} \mathrm{K}_{2} \mathrm{CO}_{3}$ ( $2.25 \mathrm{mmol}, 4.5$ eq.), and $12 \mathrm{mg}[\mathrm{RhCl}(\mathrm{cod})]_{2}(0.025 \mathrm{mmol}$, 0.05 eq.) in $2 \mathrm{~cm}^{3}$ dry and degassed toluene. The reaction mixture was heated for $22 \mathrm{~h}$ at $160^{\circ} \mathrm{C}$. The general work-up procedure $\mathrm{B}$ for $\mathrm{C}-\mathrm{H}$ activation reactions was followed. The combined organic layers were evaporated and the resulting crude product was purified by flash column chromatography (LP/EtOAc, $45 \mathrm{~g} \mathrm{SiO}_{2}$, flowrate $30 \mathrm{~cm}^{3} / \mathrm{min}$ ) starting with pure LP for $10 \mathrm{~min}$. Then, the flash column chromatography was continued using a gradient which varies the solvents from 0\% to 5\% EtOAc within 45 min. Drying under reduced pressure delivered $\mathbf{1 3}$ in 55\% (90 $\mathrm{mg}$ ) yield as pale yellowish oil. TLC: $R_{\mathrm{f}}=0.67$ (LP/EtOAc 10:1); ${ }^{1} \mathrm{H}$ NMR $\left(400 \mathrm{MHz}, \mathrm{CDCl}_{3}\right): \delta=0.87(\mathrm{dd}, J=6.6,3.5 \mathrm{~Hz}, 6 \mathrm{H}, \mathrm{C}[6$, 7]- $\left.\mathrm{H}_{3}\right), 1.09-1.39\left(\mathrm{~m}, 2 \mathrm{H}, \mathrm{C}[3]-\mathrm{H}_{2}\right), 1.58(\mathrm{dp}, J=13.3$, $6.7 \mathrm{~Hz}, 1 \mathrm{H}, \mathrm{C}[5]-\mathrm{H}), 1.73-2.00\left(\mathrm{~m}, 2 \mathrm{H}, \mathrm{C}[4]-\mathrm{H}_{2}\right), 2.12$ $\left(\mathrm{s}, 3 \mathrm{H}, \mathrm{C}[7 \mathrm{a}]-\mathrm{H}_{3}\right), 4.39(\mathrm{~d}, J=7.5 \mathrm{~Hz}, 1 \mathrm{H}, \mathrm{N}-\mathrm{H}), 5.23$ (q, $J=7.2 \mathrm{~Hz}, 1 \mathrm{H}, \mathrm{C}[2]-\mathrm{H}), 6.47(\mathrm{dd}, J=7.1,5.1 \mathrm{~Hz}, 1 \mathrm{H}$, C[5a]-H), 7.14-7.25 (m, 2H, C[4a; 4b]-H), 7.27-7.42 (m, $4 \mathrm{H}, \mathrm{C}[2 \mathrm{~b} ; 3 \mathrm{~b} ; 5 \mathrm{~b} ; 6 \mathrm{~b}]-\mathrm{H}), 7.95(\mathrm{dd}, J=6.0,1.8 \mathrm{~Hz}, 1 \mathrm{H}$, $\mathrm{C}[6 \mathrm{a}]-\mathrm{H}) \mathrm{ppm} ;{ }^{13} \mathrm{C} \mathrm{NMR}\left(101 \mathrm{MHz}, \mathrm{CDCl}_{3}\right): \delta=17.2(\mathrm{q}$, C[6, 7]), 22.7 (q, C[7a]), 28.2 (d, C[5]), 35.4 (t, C[4]), 35.6 (t, C[3]), 55.0 (d, C[2]), 112.6 (d, C[5a]), 116.4 (s, C[3a]), 126.7 (d, C[2b; 6b]), 126.9 (d, C[4b]), 128.5 (d, C[3b; 5b]), 137.0 (d, C[4a]), 144.6 (s, C[1b]), 145.5 (d, C[6a]), 156.2 (s, C[2a]) ppm; GC-MS: retention time: $9.97 \mathrm{~min}$; main fragments: $m / z(\%)=268\left(\mathrm{M}^{+}, 6\right), 211(17), 197(100), 108$ (30), $91(20)$.

$\mathrm{N}$-(1,3-Diphenylpropyl)-3-methylpyridin-2-amine (14, $\left.\mathrm{C}_{21} \mathrm{H}_{22} \mathrm{~N}_{2}\right)$ The reaction was carried out according to general procedure A with $100 \mathrm{mg} 1(0.50 \mathrm{mmol}, 1$ eq.), $278 \mathrm{mg}$ (2-bromoethyl)benzene ( $1.50 \mathrm{mmol}, 3$ eq.), $311 \mathrm{mg} \mathrm{K} \mathrm{CO}_{3}$ ( $2.25 \mathrm{mmol}, 4.5$ eq.), and $12 \mathrm{mg}[\mathrm{RhCl}(\mathrm{cod})]_{2}(0.025 \mathrm{mmol}$, 0.05 eq.) in $2 \mathrm{~cm}^{3}$ dry and degassed toluene. The reaction mixture was heated for $22 \mathrm{~h}$ at $160{ }^{\circ} \mathrm{C}$. The general work-up procedure $\mathrm{B}$ for $\mathrm{C}-\mathrm{H}$ activation reactions was followed. The combined organic layers were evaporated and the resulting crude product was purified by flash column chromatography (LP/EtOAc, $45 \mathrm{~g} \mathrm{SiO}_{2}$, flowrate $30 \mathrm{~cm}^{3} / \mathrm{min}$ ) starting with pure LP for $10 \mathrm{~min}$. Then, the flash column chromatography was continued using a gradient which varies the solvents from $0 \%$ to 5\% EtOAc within $45 \mathrm{~min}$. Drying under reduced pressure delivered $\mathbf{1 4}$ in $23 \%$ (36 mg) yield as pale yellowish oil. TLC: $R_{\mathrm{f}}=0.46(\mathrm{LP} / \mathrm{EtOAc} 10: 1) ;{ }^{1} \mathrm{H}$ NMR

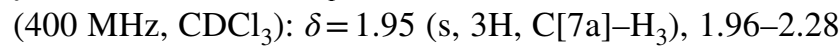
(m, 2H, C[4]-H), 2.70 (dddd, $J=51.9,14.0,9.8,6.0 \mathrm{~Hz}, 2 \mathrm{H}$, $\left.\mathrm{C}[3]-\mathrm{H}_{2}\right), 4.27-4.34(\mathrm{~m}, 1 \mathrm{H}, \mathrm{N}-\mathrm{H}), 5.30(\mathrm{q}, J=7.1 \mathrm{~Hz}, 1 \mathrm{H}$, C[2]-H), 6.40 (dd, $J=7.1,5.1 \mathrm{~Hz}, 1 \mathrm{H}, \mathrm{C}[5 \mathrm{a}]-\mathrm{H}), 7.04-7.28$ (m, 9H, C[2b; 3b; 5b; 6b; 2c-6c]-H), 7.28-7.36 (m, 2H, $\mathrm{C}[4 \mathrm{a} ; 4 \mathrm{~b}]-\mathrm{H}), 7.88(\mathrm{dd}, J=5.2,1.8 \mathrm{~Hz}, 1 \mathrm{H}, \mathrm{C}[6 \mathrm{a}]-\mathrm{H}) \mathrm{ppm}$; ${ }^{13} \mathrm{C}$ NMR (101 MHz, $\mathrm{CDCl}_{3}$ ): $\delta=17.0$ (q, C[7]), $32.8(\mathrm{t}$, C[4]), 38.9 (t, C[3]), 54.7 (d, C[2]), 112.7 (s, C[3a]), 116.4 (d, C[5a]), 125.9 (d, C[2b; 6b]), 126.6 (d, C[4b]), 127.0 (d, C[3b; 5b]), 127.7 (d, C[4c]), 128.5 (d, C[3c; 5c]), 128.6 (d, C[2c; 6c]), 136.9 (d, C[4a]), 142.1 (s, C[1c]), 144.1 (s, C[1b]), 145.4 (d, C[6a]), 156.0 (s, C[2a]) ppm; GC-MS: retention time: $8.50 \mathrm{~min}$; main fragments: $\mathrm{m} / \mathrm{z}(\%)=302$ $\left(\mathrm{M}^{+}, 9\right), 211$ (85), 197 (100), 108 (20), 91 (52), 65 (30).

3-Methyl-N-(2-methylbenzyl)pyridin-2-amine (15, $\mathrm{C}_{14} \mathrm{H}_{16} \mathrm{~N}_{2}$ ) The reaction was carried out according to general procedure $\mathrm{C}$ with $67 \mathrm{mg} \mathrm{Pd}(\mathrm{OAc})_{2}(0.3 \mathrm{mmol}, 0.02$ 
equiv.), $187 \mathrm{mg}$ rac. BINAP ( $0.3 \mathrm{mmol}, 0.02$ equiv.), $7.26 \mathrm{~g}$ $\mathrm{K}_{2} \mathrm{CO}_{3}$ (52.5 mmol, 3.5 equiv.), $1.91 \mathrm{~g}$ 2-chloro-3-methylpyridine (15 mmol, 1 equiv.), $2.18 \mathrm{~g}$ 2-methylbenzylamine (18 mmol, 1.2 equiv.), and $38 \mathrm{~cm}^{3}$ toluene. The yield of the thereby prepared yellow crystals is $73 \%(2.34 \mathrm{~g})$. TLC: $R_{\mathrm{f}}=0.2(\mathrm{LP} / \mathrm{EtOAc} 10: 1) ;{ }^{1} \mathrm{H}$ NMR $\left(400 \mathrm{MHz}, \mathrm{CDCl}_{3}\right)$ : $\delta=2.07(\mathrm{~s}, 3 \mathrm{H}, \mathrm{C}[7 \mathrm{a}]-\mathrm{H} 3), 2.39$ (s, 3H, C[7b]-H3), 4.20 (s, 1H, N[1]-H), $4.66\left(\mathrm{~d}, J=4.9 \mathrm{~Hz}, 2 \mathrm{H}, \mathrm{C}[2]-\mathrm{H}_{2}\right), 6.57$ (dd, $J=7.0,5.2 \mathrm{~Hz}, 1 \mathrm{H}, \mathrm{C}[5 \mathrm{a}]-\mathrm{H}), 7.20(\mathrm{~m}, 3 \mathrm{H}, \mathrm{C}[4 \mathrm{a} ; 2 \mathrm{~b}$; 4b]), 7.25 (d, $J=6.6 \mathrm{~Hz}, 1 \mathrm{H}, \mathrm{C}[3 \mathrm{~b}]), 7.34(\mathrm{~d}, J=6.6 \mathrm{~Hz}$, $1 \mathrm{H}, \mathrm{C}[5 \mathrm{~b}]), 8.07$ (d, $J=4.2 \mathrm{~Hz}, 1 \mathrm{H}, \mathrm{C}[6 \mathrm{a}]) \mathrm{ppm} ;{ }^{13} \mathrm{C} \mathrm{NMR}$ $\left(101 \mathrm{MHz}, \mathrm{CDCl}_{3}\right): \delta=17.1$ (q, C[7a]), 19.2 (q, C[7b]), 44.3 (t, C[2]), 112.9 (d, C[5a]), 116.7 (s, C[3a]), 126.2 (d, C[2b]), 127.6 (d, C[4b]), 128.8 (d, C[5b]), 130.6 (d, C[4a]), 136.9 (s, C[2b]), 137.0 (d, C[3b]), 137.6 (s, C[1b]) 145.4 (d, C[6a]), 156.7 (s, C[2a]) ppm.

$\mathrm{N}$-(3-Methoxybenzyl)-3-methylpyridin-2-amine (16, $\mathrm{C}_{14} \mathrm{H}_{16} \mathrm{~N}_{2} \mathrm{O}$ ) The reaction was carried out according to general procedure $\mathrm{C}$ with $29 \mathrm{mg} \mathrm{Pd}(\mathrm{OAc})_{2}(0.13 \mathrm{mmol}, 0.02$ equiv.), $77 \mathrm{mg}$ rac. BINAP ( $0.12 \mathrm{mmol}, 0.02$ equiv.), $2.93 \mathrm{~g}$ $\mathrm{K}_{2} \mathrm{CO}_{3}$ (21.2 mmol, 3.5 equiv.), $0.78 \mathrm{~g}$ 2-chloro-3-methylpyridine (6.1 mmol, 1 equiv.), $1.0 \mathrm{~g} 3$-methoxybenzylamine (7.3 mmol, 1.2 equiv.), and $30 \mathrm{~cm}^{3}$ toluene. The yield of the thereby prepared white solid is $64 \%(0.41 \mathrm{~g}) .{ }^{1} \mathrm{H}$ NMR $\left(400 \mathrm{MHz}, \mathrm{CDCl}_{3}\right): \delta=2.10\left(\mathrm{~s}, 3 \mathrm{H}, \mathrm{C}[7 \mathrm{a}]-\mathrm{H}_{3}\right), 3.80(\mathrm{~s}, 3 \mathrm{H}$, $\left.\mathrm{C}[8 \mathrm{~b}]-\mathrm{H}_{3}\right), 4.42(\mathrm{~s}, 1 \mathrm{H}, \mathrm{N}[1]-\mathrm{H}), 4.68(\mathrm{~d}, J=5.2 \mathrm{~Hz}, 2 \mathrm{H}$, $\left.\mathrm{C}[2]-\mathrm{H}_{2}\right), 6.56(\mathrm{dd}, J=7.0,5.2 \mathrm{~Hz}, 1 \mathrm{H}, \mathrm{C}[2 \mathrm{~b}]-\mathrm{H}), 6.83$ (dd, $J=8.2,2.1 \mathrm{~Hz}, 1 \mathrm{H}, \mathrm{C}[4 \mathrm{~b}]-\mathrm{H}), 7.03-6.92$ (m, 2H, C[5a; 6b]), 7.33-7.19 (m, 2H, C[4a; 5b]), 8.05 (d, J=6.0 Hz, 1H, C[6a]) ppm; ${ }^{13} \mathrm{C}$ NMR (101 MHz, $\mathrm{CDCl}_{3}$ ): $\delta=17.0$ (q, C [7a]), 45.9 (q, C[8b]), 55.2 (d, C [2]), 112.6 (d, C[2b]), 113.0 (d, C [4b]), 113.5 (d, C[5a]), 116.7 (s, C[3a]), 120.1 (d, C[6b]), 129.6 (d, C[5b]), 137.0 (d, C[4a]), 141.6 (s, C[1b]), 145.25 (d, C[6a]), 156.6 (s, C[3b]), 159.86 (s, C[3a]) ppm.

\section{3-Methyl- $N$-[4-(trifluoromethyl)benzyl]pyridin-2-amine}

(17) [20] The reaction was carried out according to general procedure $\mathrm{C}$ with $67 \mathrm{mg} \mathrm{Pd}(\mathrm{OAc})_{2}(0.3 \mathrm{mmol}, 0.02$ equiv.), $187 \mathrm{mg}$ rac. BINAP ( $0.3 \mathrm{mmol}, 0.02$ equiv.), $7.26 \mathrm{~g} \mathrm{~K}_{2} \mathrm{CO}_{3}$ (52.5 mmol, 3.5 equiv.), $1.91 \mathrm{~g}$ 2-chloro-3-methylpyridine (15 mmol, 1 equiv.), 3.15 g 4-(trifluoromethyl)benzylamine (18 mmol, 1.2 equiv.), and $38 \mathrm{~cm}^{3}$ toluene. The yield of the thereby prepared yellow crystals is $81 \%$ ( $3.24 \mathrm{~g}$ ).

\section{Ethyl 5-[(3-methylpyridin-2-yl)amino]-5-phenylpentanoate} $\left(18, \mathrm{C}_{19} \mathrm{H}_{24} \mathrm{~N}_{2} \mathrm{O}_{2}\right)$ The reaction was carried out according to general procedure A with $100 \mathrm{mg} 1(0.50 \mathrm{mmol}, 1 \mathrm{eq}$. $)$, $293 \mathrm{mg}$ ethyl 4-bromobutyrate ( $1.50 \mathrm{mmol}, 3$ eq.), $311 \mathrm{mg}$ $\mathrm{K}_{2} \mathrm{CO}_{3}(2.25 \mathrm{mmol}, 4.5$ eq. $)$, and $12 \mathrm{mg}[\mathrm{RhCl}(\operatorname{cod})]_{2}$ $\left(0.025 \mathrm{mmol}, 0.05\right.$ eq.) in $2 \mathrm{~cm}^{3}$ dry and degassed toluene. The reaction mixture was heated for $22 \mathrm{~h}$ at $160{ }^{\circ} \mathrm{C}$. The general work-up procedure $\mathrm{B}$ for $\mathrm{C}-\mathrm{H}$ activation reactions was followed. The combined organic layers were evaporated and the resulting crude product was purified by flash column chromatography (LP/EtOAc, $9 \mathrm{~g} \mathrm{SiO}_{2}$, flowrate $15 \mathrm{~cm}^{3} / \mathrm{min}$ ) using a gradient which varies the solvents from $0 \%$ to $5 \%$ EtOAc within 45 min. Drying under reduced pressure delivered 18 in $26 \%$ (41 mg) yield as dark yellowish oil. TLC: $R_{\mathrm{f}}=0.16$ (LP/EtOAc 10:1); ${ }^{1} \mathrm{H}$ NMR $\left(400 \mathrm{MHz}, \mathrm{CDCl}_{3}\right)$ : $\delta=1.05-1.25\left(\mathrm{~m}, 3 \mathrm{H}, \mathrm{C}[9]-\mathrm{H}_{3}\right), 1.46-1.95(\mathrm{~m}, 4 \mathrm{H}, \mathrm{C}[3,4]-$ $\left.\mathrm{H}_{2}\right), 2.02\left(\mathrm{~s}, 3 \mathrm{H}, \mathrm{C}[7 \mathrm{a}]-\mathrm{H}_{3}\right), 2.11-2.35\left(\mathrm{~m}, 2 \mathrm{H}, \mathrm{C}[5]-\mathrm{H}_{2}\right)$, $4.01\left(\mathrm{q}, J=7.1 \mathrm{~Hz}, 2 \mathrm{H}, \mathrm{C}[8]-\mathrm{H}_{2}\right), 4.38(\mathrm{~d}, J=7.7 \mathrm{~Hz}, 1 \mathrm{H}$, $\mathrm{N}-\mathrm{H}), 5.19$ (q, $J=7.1 \mathrm{~Hz}, 1 \mathrm{H}, \mathrm{C}[2]-\mathrm{H}), 6.38$ (dd, $J=7.1$, $5.1 \mathrm{~Hz}, 1 \mathrm{H}, \mathrm{C}[5 \mathrm{a}]-\mathrm{H}), 7.07-7.15(\mathrm{~m}, 2 \mathrm{H}, \mathrm{C}[4 \mathrm{a} ; 4 \mathrm{~b}]-\mathrm{H})$, 7.17-7.37 (m, 4H, C[2b; 3b; 5b; 6b]-H), 7.85 (dd, $J=5.2$, $1.7 \mathrm{~Hz}, 1 \mathrm{H}, \mathrm{C}[6 \mathrm{a}]-\mathrm{H}) \mathrm{ppm} ;{ }^{13} \mathrm{C}$ NMR $\left(101 \mathrm{MHz}, \mathrm{CDCl}_{3}\right)$ : $\delta=14.3(\mathrm{q}, \mathrm{C}[9]), 17.1$ (q, C[7a]), $21.8(\mathrm{t}, \mathrm{C}[3]), 34.0(\mathrm{t}$, C[4]), 36.7 (t, C[5]), 54.3 (d, C[2]), 60.3 (d, C[8]), 112.7 (d, C[5a]), 116.4 (s, C[3a]), 126.5 (d, C[2b; 6b]), 126.9 (d, C[4b]), 128.5 (d, C[3b; 5b]), 136.9 (d, C[4a]), 144.0 (s, C[1b]), 145.4 (d, C[6a]), 156.1 (s, C[2a]), 173.5 (s, C[6]) ppm; GC-MS: retention time: $8.10 \mathrm{~min}$; main fragments: $\mathrm{m} / \mathrm{z}(\%)=312\left(\mathrm{M}^{+}, 16\right), 267$ (10), 211 (42), 197 (100), 117 (10), 108 (25), 91 (15), 65 (16).

\section{Ethyl 6-[(3-methylpyridin-2-yl)amino]-6-phenylhexanoate} $\left(19, \mathrm{C}_{20} \mathrm{H}_{26} \mathrm{~N}_{2} \mathrm{O}_{2}\right)$ The reaction was carried out according to general procedure A with $100 \mathrm{mg} 1(0.50 \mathrm{mmol}, 1 \mathrm{eq}$. $)$, $314 \mathrm{mg}$ ethyl 5-bromopentanoate ( $1.50 \mathrm{mmol}, 3 \mathrm{eq}.), 311 \mathrm{mg}$ $\mathrm{K}_{2} \mathrm{CO}_{3}$ (2.25 mmol, 4.5 eq.), and $12 \mathrm{mg}[\mathrm{RhCl}(\mathrm{cod})]_{2}$ ( $0.025 \mathrm{mmol}, 0.05$ eq. $)$ in $2 \mathrm{~cm}^{3}$ dry and degassed toluene. The reaction mixture was heated for $22 \mathrm{~h}$ at $160{ }^{\circ} \mathrm{C}$. The general work-up procedure $\mathrm{B}$ for $\mathrm{C}-\mathrm{H}$ activation reactions was followed using a gradient which varies the solvents from $0 \%$ to $10 \%$ EtOAc within 45 min. Drying under reduced pressure delivered 19 in 35\% (56 mg) yield. TLC: $R_{\mathrm{f}}=0.16(\mathrm{LP} / \mathrm{EtOAc} 10: 1) ;{ }^{1} \mathrm{H}$ NMR $\left(400 \mathrm{MHz}, \mathrm{CDCl}_{3}\right)$ : $\delta=1.13\left(\mathrm{t}, J=7.1 \mathrm{~Hz}, 3 \mathrm{H}, \mathrm{C}[10]-\mathrm{H}_{3}\right), 1.17-1.47(\mathrm{~m}, 2 \mathrm{H}$, $\left.\mathrm{C}[4]-\mathrm{H}_{2}\right), 1.58\left(\mathrm{p}, J=7.6 \mathrm{~Hz}, 2 \mathrm{H}, \mathrm{C}[5]-\mathrm{H}_{2}\right), 1.70-1.95(\mathrm{~m}$, $\left.2 \mathrm{H}, \mathrm{C}[3]-\mathrm{H}_{2}\right), 2.02\left(\mathrm{~s}, 3 \mathrm{H}, \mathrm{C}[7 \mathrm{a}]-\mathrm{H}_{3}\right), 2.19(\mathrm{t}, J=7.5 \mathrm{~Hz}$,

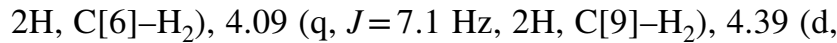
$J=7.8 \mathrm{~Hz}, 1 \mathrm{H}, \mathrm{N}-\mathrm{H}), 5.26(\mathrm{q}, J=7.3 \mathrm{~Hz}, 1 \mathrm{H}, \mathrm{C}[2]-\mathrm{H}), 6.47$ (dd, $J=7.1,5.1 \mathrm{~Hz}, 1 \mathrm{H}, \mathrm{C}[5 \mathrm{a}]-\mathrm{H}), 7.15-7.24(\mathrm{~m}, 2 \mathrm{H}, \mathrm{C}[4 \mathrm{a}$; 4b]-H), 7.27-7.44 (m, 4H, C[2b; 3b; 5b; 6b]-H), 7.95 (dd, $J=5.2,1.8 \mathrm{~Hz}, 1 \mathrm{H}, \mathrm{C}[6 \mathrm{a}]-\mathrm{H}) \mathrm{ppm} ;{ }^{13} \mathrm{C}$ NMR $(101 \mathrm{MHz}$, $\mathrm{CDCl}_{3}$ ): $\delta=14.2$ (q, C[10]), 17.1 (q, C[7a]), 24.9 (t, C[5]), 25.9 (t, C[4]), 34.2 (t, C[3]), 37.0 (t, C[6]), 54.6 (d, C[2]), 60.2 (t, C[9]), 112.6 (d, C[5a]), 116.4 (s, C[3a]), 126.5 (d, $\mathrm{C}[2 \mathrm{~b} ; 6 \mathrm{~b}]), 126.9$ (d, C[4b]), 128.5 (d, C[3b; 5b]), 137.0 (d, C[4a]), 144.1 (d, C[6a]), 155.9 (s, C[2a]), 173.7 (s, C[7]) ppm; GC-MS: retention time: 8.41 min; main fragments: $m / z(\%)=326\left(\mathrm{M}^{+}, 12\right), 281(9), 197$ (100), 108 (20), 91 (19), 65 (10). 
$\mathrm{N}$-[1-(3-Methoxyphenyl)pentyl]-3-methylpyridin-2-amine $\left(20, \mathrm{C}_{18} \mathrm{H}_{24} \mathrm{~N}_{2} \mathrm{O}\right)$ The reaction was carried out according to general procedure A with $114 \mathrm{mg} 16(0.50 \mathrm{mmol}, 1$ eq. $)$, $206 \mathrm{mg}$ 1-bromobutane ( $1.50 \mathrm{mmol}, 3$ eq.), $311 \mathrm{mg} \mathrm{K} \mathrm{CO}_{3}$ ( $2.25 \mathrm{mmol}, 4.5$ eq.), and $12 \mathrm{mg}[\mathrm{RhCl}(\mathrm{cod})]_{2}(0.025 \mathrm{mmol}$, 0.05 eq.) in $2 \mathrm{~cm}^{3}$ dry and degassed toluene. The reaction mixture was heated for $22 \mathrm{~h}$ at $160{ }^{\circ} \mathrm{C}$. The general work-up procedure $\mathrm{B}$ for $\mathrm{C}-\mathrm{H}$ activation reactions was followed using a gradient which varies the solvents from $0 \%$ to $10 \%$ EtOAc within $45 \mathrm{~min}$. Drying under reduced pressure delivered 20 in $56 \%(80 \mathrm{mg})$ yield. TLC: $R_{\mathrm{f}}=0.42(\mathrm{LP} / \mathrm{EtOAc} 10: 1) ;{ }^{1} \mathrm{H}$ NMR (400 MHz, $\left.\mathrm{CDCl}_{3}\right): \delta=0.90(\mathrm{t}, J=7.0 \mathrm{~Hz}, 3 \mathrm{H}, \mathrm{C}[6]-$ $\left.\mathrm{H}_{3}\right), 1.24-1.52$ (m, 4H, C[3, 5]- $\mathrm{H}_{2}$ ), 1.89 (tdt, $J=16.4,9.6$, $\left.4.5 \mathrm{~Hz}, 2 \mathrm{H}, \mathrm{C}[4]-\mathrm{H}_{2}\right), 1.89$ (tdt, $J=16.4,9.6,4.5 \mathrm{~Hz}, 2 \mathrm{H}$, $\left.\mathrm{C}[19]-\mathrm{H}_{2}\right), 2.14\left(\mathrm{~s}, 3 \mathrm{H}, \mathrm{C}[7 \mathrm{a}]-\mathrm{H}_{3}\right), 3.82\left(\mathrm{~s}, 3 \mathrm{H}, \mathrm{C}[8 \mathrm{~b}]-\mathrm{H}_{3}\right)$, $4.42(\mathrm{~s}, 1 \mathrm{H}, \mathrm{N}-\mathrm{H}), 5.26(\mathrm{q}, J=7.5 \mathrm{~Hz}, 1 \mathrm{H}, \mathrm{C}[2]-\mathrm{H}), 6.50$ (dd, $J=7.1,5.1 \mathrm{~Hz}, 1 \mathrm{H}, \mathrm{C}[4 \mathrm{~b}]-\mathrm{H}), 6.78$ (ddd, $J=8.1,2.6$, $1.1 \mathrm{~Hz}, 1 \mathrm{H}, \mathrm{C}[5 \mathrm{a}]-\mathrm{H}), 6.93-7.03(\mathrm{~m}, 2 \mathrm{H}, \mathrm{C}[2 \mathrm{~b} ; 6 \mathrm{~b}]-\mathrm{H})$, 7.18-7.30 (m, 2H, C[4a; 4b]-H), 7.98 (dd, $J=5.1,1.8 \mathrm{~Hz}$, $1 \mathrm{H}, \mathrm{C}[6 \mathrm{a}]-\mathrm{H}) \mathrm{ppm} ;{ }^{13} \mathrm{C} \mathrm{NMR}\left(101 \mathrm{MHz}, \mathrm{CDCl}_{3}\right): \delta=14.0$ (q, C[6]), 17.1 (q, C[7a]), 22.7 (t, C[4]), 28.5 (t, C[3]), 54.7 (d, C[2]), 55.2 (q, C[8b]), 111.8 (d, C[2b]), 112.6 (d, C[4b]), 112.7 (d, C[5b]), 116. 5 (s, C[3a]), 118.9 (d, C[6b]), 129.4 (d, C[5a]), 137.1 (d, C[4a]), 145.0 (d, C[6a]), 146.2 (s, C[1b]), 155.9 (s, C[3b]), 159. 7 (s, C[2a]) ppm; GC-MS: retention time: $8.41 \mathrm{~min}$; main fragments: $\mathrm{m} / z(\%)=326$ $\left(\mathrm{M}^{+}, 12\right), 281$ (9), 197 (100), 108 (20), 91 (19), 65 (10).

\section{$N$-[1-(3-Methoxyphenyl)undecyl]-3-methylpyridin-2-amine} $\left(21, \mathrm{C}_{24} \mathrm{H}_{36} \mathrm{~N}_{2} \mathrm{O}\right)$ The reaction was carried out according to general procedure A with $114 \mathrm{mg} 16(0.50 \mathrm{mmol}, 1$ eq. $)$, $332 \mathrm{mg}$ 1-bromodecane ( $1.50 \mathrm{mmol}, 3$ eq.), $311 \mathrm{mg} \mathrm{K}_{2} \mathrm{CO}_{3}$ ( $2.25 \mathrm{mmol}, 4.5$ eq.), and $12 \mathrm{mg}[\mathrm{RhCl}(\mathrm{cod})]_{2}(0.025 \mathrm{mmol}$, 0.05 eq.) in $2 \mathrm{~cm}^{3}$ dry and degassed toluene. The reaction mixture was heated for $22 \mathrm{~h}$ at $160^{\circ} \mathrm{C}$. The general work-up procedure $\mathrm{B}$ for $\mathrm{C}-\mathrm{H}$ activation reactions was followed using a gradient which varies the solvents from $0 \%$ to $5 \%$ EtOAc within $45 \mathrm{~min}$. Drying under reduced pressure delivered 21 in 56\% (102 mg) yield. TLC: $R_{\mathrm{f}}=0.65$ (LP/EtOAc 10:1); ${ }^{1} \mathrm{H}$ NMR (400 MHz, $\left.\mathrm{CDCl}_{3}\right): \delta=0.91(\mathrm{t}, J=6.9 \mathrm{~Hz}, 3 \mathrm{H}, \mathrm{C}[12]-$ $\left.\mathrm{H}_{3}\right), 1.19-1.51\left(\mathrm{~m}, 16 \mathrm{H}, \mathrm{C}[4-11]-\mathrm{H}_{2}\right), 1.81-1.97(\mathrm{~m}, 2 \mathrm{H}$, $\left.\mathrm{C}[3]-\mathrm{H}_{2}\right), 2.15$ (s, 3H, C[7a]- $\left.\mathrm{H}_{3}\right), 3.82\left(\mathrm{~s}, 3 \mathrm{H}, \mathrm{C}[8 \mathrm{~b}]-\mathrm{H}_{3}\right)$, $4.41-4.48(\mathrm{~m}, 1 \mathrm{H}, \mathrm{N}-\mathrm{H}), 5.27(\mathrm{q}, J=7.3 \mathrm{~Hz}, 1 \mathrm{H}, \mathrm{C}[2]-$ $\mathrm{H}), 6.51(\mathrm{dd}, J=7.1,5.1 \mathrm{~Hz}, 1 \mathrm{H}, \mathrm{C}[5 \mathrm{a}]-\mathrm{H}), 6.75-6.83(\mathrm{~m}$, $1 \mathrm{H}, \mathrm{C}[4 \mathrm{~b}]-\mathrm{H}), 6.94-7.04$ (m, 2H, C[5b; 6b]-H), 7.25 (q, $J=7.5 \mathrm{~Hz}, 2 \mathrm{H}, \mathrm{C}[2 \mathrm{~b} ; 4 \mathrm{a}]-\mathrm{H}), 7.99$ (dd, $J=5.2,1.8 \mathrm{~Hz}, 1 \mathrm{H}$, $\mathrm{C}[6 \mathrm{a}]-\mathrm{H}) \mathrm{ppm} ;{ }^{13} \mathrm{C} \mathrm{NMR}\left(101 \mathrm{MHz}, \mathrm{CDCl}_{3}\right): \delta=14.1$ (q, C[12]), 17.1 (q, C[7a]), 22.7 (t, C[11]), 26.4 (t, C[4]), 29.31 (t, C[5]), 29.60 (t, C[6-9]), 31.9 (t, C[10]), 37.5 (t, C[3]), 54.7 (d, C[2]), 55.2 (q, C[8b]), 111.8 (d, C[6b]), 112.5 (d, C[4b]), 112.6 (d, C[5a]), 116.4 (s, C[3a]), 118.8 (d, C[2b]), 129. 4 (d, C[5a]), 137.6 (d, C[4a]), 145.3 (s, C[1b]), 146.2 (d, C[6a]), 156.6 (s, C[5b]), 159.7 (s, C[2a]) ppm; GC-MS: retention time: $9.48 \mathrm{~min}$; main fragments: $\mathrm{m} / \mathrm{z}(\%)=368$ ( $\left.\mathrm{M}^{+}, 9\right), 241$ (21), 227 (100), 207 (6), 108 (26), 91 (6) 65 (5).

3-Methyl- $N$-[1-(o-tolyl)pentyl]pyridin-2-amine (22, $\mathrm{C}_{18} \mathrm{H}_{24} \mathrm{~N}_{2}$ ) The reaction was carried out according to general procedure A with $100 \mathrm{mg} 15$ (0.47 mmol, 1 eq.), $206 \mathrm{mg}$ 1-bromobutane (1.50 mmol, 3.2 eq.), $311 \mathrm{mg} \mathrm{K} \mathrm{CO}_{3}$ ( $2.25 \mathrm{mmol}, 4.5$ eq.), and $12 \mathrm{mg}[\mathrm{RhCl}(\mathrm{cod})]_{2}(0.025 \mathrm{mmol}$, 0.05 eq.) in $2 \mathrm{~cm}^{3}$ dry and degassed toluene. The reaction mixture was heated for $22 \mathrm{~h}$ at $160{ }^{\circ} \mathrm{C}$. The general work-up procedure $\mathrm{B}$ for $\mathrm{C}-\mathrm{H}$ activation reactions was followed using a gradient which varies the solvents from $0 \%$ to $5 \%$ EtOAc within $1 \mathrm{~h}$. Thereafter, a gradient that varies the solvents from 5\% to $10 \%$ EtOAc was applied. Drying delivered 22 in $47 \%(60 \mathrm{mg})$ yield as colorless oil. TLC: $R_{\mathrm{f}}=0.6(\mathrm{LP} / \mathrm{EtOAc}$ 10:1); ${ }^{1} \mathrm{H}$ NMR $\left(400 \mathrm{MHz}, \mathrm{CDCl}_{3}\right): \delta=0.87(\mathrm{t}, J=7.0 \mathrm{~Hz}$, $\left.3 \mathrm{H}, \mathrm{C}[6]-\mathrm{H}_{3}\right), 1.19-1.46\left(\mathrm{~m}, 4 \mathrm{H}, \mathrm{C}[4,5]-\mathrm{H}_{2}\right), 1.74-1.99(\mathrm{~m}$, $\left.2 \mathrm{H}, \mathrm{C}[3]-\mathrm{H}_{2}\right), 2.11$ (s, 3H, C[7a]- $\left.\mathrm{H}_{3}\right), 2.32$ (s, 3H, C[7b]$\left.\mathrm{H}_{3}\right), 4.39(\mathrm{~s}, 1 \mathrm{H},(\mathrm{m}, 1 \mathrm{H}, \mathrm{N}-\mathrm{H})), 5.22(\mathrm{q}, J=7.5 \mathrm{~Hz}, 1 \mathrm{H}$, C[2]-H), 6.47 (dd, $J=7.1,5.1 \mathrm{~Hz}, 1 \mathrm{H}, \mathrm{C}[5 \mathrm{a}]-\mathrm{H}), 7.12(\mathrm{~d}$, $J=7.8 \mathrm{~Hz}, 2 \mathrm{H}, \mathrm{C}[4 \mathrm{a} ; 4 \mathrm{~b}]), 7.23-7.16(\mathrm{~m}, 1 \mathrm{H}, \mathrm{C}[2 \mathrm{~b}]), 7.27$ $(\mathrm{d}, J=8.1 \mathrm{~Hz}, 2 \mathrm{H}, \mathrm{C}[3 \mathrm{~b} ; 5 \mathrm{~b}]), 7.96(\mathrm{dd}, J=5.1,1.8 \mathrm{~Hz}, 1 \mathrm{H}$, $\mathrm{C}[6 \mathrm{a}]-\mathrm{H}) \mathrm{ppm} ;{ }^{13} \mathrm{C} \mathrm{NMR}\left(101 \mathrm{MHz}, \mathrm{CDCl}_{3}\right): \delta=14.1$ (q, C[12]), 17.2 (q, C[7a]), 21.2 (t, C[7b], 22.8 (t, C[4]), 28.7 (t, C[5]), 37.3 (t, C[3]), 54.5 (d, C[2]), 112.5 (d, C[5a]), 116.4 (s, C[3a]), 126.6 (d, C[2b]), 129.2 (d, C[4b]), 136.6 (d, C[4a]), 137.0 (d, C[3b]), 141.6 (s, C[1b]), 156.2 (d, C[5b]) ppm; GC-MS: retention time: $8.88 \mathrm{~min}$; main fragments: $\mathrm{m} / \mathrm{z}(\%)=352\left(\mathrm{M}^{+}, 5\right), 225(8), 211(100), 108(19), 92(22)$ 65 (4).

3-Methyl- $N$-[1-(o-tolyl)undecyl]pyridin-2-amine (23, $\left.\mathrm{C}_{24} \mathrm{H}_{36} \mathrm{~N}_{2}\right)$ The reaction was carried out according to general procedure A with $106 \mathrm{mg} 17$ (0.50 mmol, 1 eq.), $332 \mathrm{mg}$ 1-bromodecane (1.50 mmol, 3 eq.), $311 \mathrm{mg} \mathrm{K} \mathrm{CO}_{3}$ ( $2.25 \mathrm{mmol}, 4.5$ eq.), and $12 \mathrm{mg}[\mathrm{RhCl}(\mathrm{cod})]_{2}(0.025 \mathrm{mmol}$, 0.05 eq.) in $2 \mathrm{~cm}^{3}$ dry and degassed toluene. The reaction mixture was heated for $22 \mathrm{~h}$ at $160{ }^{\circ} \mathrm{C}$. The general work-up procedure $\mathrm{B}$ for $\mathrm{C}-\mathrm{H}$ activation reactions was followed using a gradient which varies the solvents from $0 \%$ to $5 \% \mathrm{EtOAc}$ within $45 \mathrm{~min}$. Drying under reduced pressure delivered $\mathbf{2 3}$ in $25 \%(44 \mathrm{mg})$ yield. TLC: $R_{\mathrm{f}}=0.8(\mathrm{LP} /$ EtOAc $5: 1) ;{ }^{1} \mathrm{H}$ NMR $\left(400 \mathrm{MHz}, \mathrm{CDCl}_{3}\right): \delta=0.92-0.86(\mathrm{~m}, 3 \mathrm{H}, \mathrm{C}[12]-$ $\left.\mathrm{H}_{3}\right), 1.39-1.20\left(\mathrm{~m}, 16 \mathrm{H}, \mathrm{C}[4-11]-\mathrm{H}_{2}\right), 1.97-1.75(\mathrm{~m}, 2 \mathrm{H}$, $\left.\mathrm{C}[3]-\mathrm{H}_{2}\right), 2.10\left(\mathrm{~s}, 3 \mathrm{H}, \mathrm{C}[7 \mathrm{a}]-\mathrm{H}_{3}\right), 2.50\left(\mathrm{~s}, 3 \mathrm{H}, \mathrm{C}[7 \mathrm{~b}]-\mathrm{H}_{3}\right)$, 4.53-4.30 (m, 1H, N-H), $5.49(\mathrm{q}, J=6.4 \mathrm{~Hz}, 1 \mathrm{H}, \mathrm{C}[2]-$ $\mathrm{H}), 6.47(\mathrm{dd}, J=7.1,5.1 \mathrm{~Hz}, 1 \mathrm{H}, \mathrm{C}[5 \mathrm{a}]-\mathrm{H}), 7.23-7.08(\mathrm{~m}$, 4H, C[2b-5b]-H), 7.36-7.30 (m, 1H, C[4a]-H), 7.97 (dd, $J=5.2,1.8 \mathrm{~Hz}, 1 \mathrm{H}, \mathrm{C}[6 \mathrm{a}]-\mathrm{H}) \mathrm{ppm} ;{ }^{13} \mathrm{C}$ NMR $(101 \mathrm{MHz}$, $\mathrm{CDCl}_{3}$ ): $\delta=14.2$ (q, C[12]), 17.1 (q, C[7a]), 19.6 (q, C[7b]), 22.7 (t, C[11]), 26.5 (t, C[9]), 29.47 (t, C[8]), 29.56 (t, C[7]), 29.63 (t, C[5]), 29.73 (t, C[6]), 31.9 (t, C[4]), 34.5 (t, C[10]), 36.8 (t, C[3]), 51.0 (d, C[2]), 112.4 (s, C[6b]), 116.1 (s, 
C[3a]), 124.8 (d, C[5a]), 126.1 (d, C[4b]), 126.5 (d, C[2b]), 130.5 (d, C[3b]), 136.2 (d, C[4a]), 142.8 (s, C[1b]), 145.4 (d, C[6a]), 156.0 (d, C[5b]), 174.0 (s, C[2a]) ppm; GC-MS: retention time: $8.88 \mathrm{~min}$; main fragments: $\mathrm{m} / \mathrm{z}(\%)=352$ $\left(\mathrm{M}^{+}, 5\right), 225$ (8), 211 (100), 108 (19), 92 (22) 65 (4).

\section{3-Methyl- $N$-[1-[4-(trifluoromethyl)phenyl]pentyl]pyri-} din-2-amine (24, $\mathrm{C}_{18} \mathrm{H}_{21} \mathrm{~F}_{3} \mathrm{~N}_{2}$ ) The reaction was carried out according to general procedure A with $133 \mathrm{mg} \mathbf{1 7}$ (0.50 mmol, 1 eq.), $206 \mathrm{mg}$ 1-bromobutane $(1.50 \mathrm{mmol}$, 3 eq.), $311 \mathrm{mg} \mathrm{K}_{2} \mathrm{CO}_{3}$ (2.25 mmol, 4.5 eq.), and $12 \mathrm{mg}$ $[\mathrm{RhCl}(\mathrm{cod})]_{2}\left(0.025 \mathrm{mmol}, 0.05\right.$ eq.) in $2 \mathrm{~cm}^{3}$ dry and degassed toluene. The reaction mixture was heated for $22 \mathrm{~h}$ at $160{ }^{\circ} \mathrm{C}$. The general work-up procedure $\mathrm{B}$ for $\mathrm{C}-\mathrm{H}$ activation reactions was followed using a gradient which varies the solvents from 0\% to 5\% EtOAc within 45 min. Drying under reduced pressure delivered $\mathbf{2 4}$ in $50 \%(81 \mathrm{mg})$ yield as pale yellowish oil. TLC: $R_{\mathrm{f}}=0.41$ (LP/EtOAc 10:1); ${ }^{1} \mathrm{H}$ NMR $\left(400 \mathrm{MHz}, \mathrm{CDCl}_{3}\right): \delta=0.89(\mathrm{t}, J=6.9 \mathrm{~Hz}, 3 \mathrm{H}$, $\left.\mathrm{C}[6]-\mathrm{H}_{3}\right), 1.18-1.49\left(\mathrm{~m}, 4 \mathrm{H}, \mathrm{C}[4,5]-\mathrm{H}_{2}\right), 1.77-1.96(\mathrm{~m}$, $\left.2 \mathrm{H}, \mathrm{C}[3]-\mathrm{H}_{2}\right), 2.16\left(\mathrm{~s}, 3 \mathrm{H}, \mathrm{C}[7 \mathrm{a}]-\mathrm{H}_{3}\right), 4.48(\mathrm{~s}, 1 \mathrm{H}, \mathrm{N}-\mathrm{H})$, $5.31(\mathrm{p}, J=7.4 \mathrm{~Hz}, 1 \mathrm{H}, \mathrm{C}[2]-\mathrm{H}), 6.50(\mathrm{dd}, J=7.1,5.1 \mathrm{~Hz}$, $1 \mathrm{H}, \mathrm{C}[5 \mathrm{a}]-\mathrm{H}), 7.23(\mathrm{~d}, J=7.1 \mathrm{~Hz}, 1 \mathrm{H}, \mathrm{C}[4 \mathrm{a}]-\mathrm{H}), 7.49$ $(\mathrm{d}, J=8.2 \mathrm{~Hz}, 2 \mathrm{H}, \mathrm{C}[2 \mathrm{~b} ; 6 \mathrm{~b}]-\mathrm{H}), 7.55(\mathrm{~d}, J=8.1 \mathrm{~Hz}, 2 \mathrm{H}$, C[3b; 5b]-H), 7.91 (dd, $J=5.1,1.8 \mathrm{~Hz}, 1 \mathrm{H}, \mathrm{C}[6 \mathrm{a}]-\mathrm{H}) \mathrm{ppm}$; ${ }^{13} \mathrm{C}$ NMR (101 MHz, $\mathrm{CDCl}_{3}$ ): $\delta=14.1$ (q, C[6]), 17.2 (q, C[7a]), 22.7 (t, C[5]), 28.6 (t, C[4]), 37.5 (t, C[3]), 54.7 (d, C[2]), 113.1 (d, C[5a]), 116.6 (s, C[3a]), 123.1 (s, C[7b]), 125.5, (d, C[3b; 5b]), 126.9 (d, C[2b; 6b]), 129.3 (s, C[6b]), 137.4 (d, C[4a]), 147.3 (s, C[1b]), 148.8 (d, C[6a]), 155.5 (s, C[2a]) ppm; GC-MS: retention time: 6.94 min; main fragments: $m / z(\%)=322\left(\mathrm{M}^{+}, 18\right), 265(100), 159(11), 108$ (41), 92 (46) 65 (24).

\section{3-Methyl- $N$-[1-[4-(trifluoromethyl)phenyl]undecyl]pyri-} din-2-amine (25, $\mathrm{C}_{24} \mathrm{H}_{33} \mathrm{~F}_{3} \mathrm{~N}_{2}$ ) The reaction was carried out according to general procedure A with $133 \mathrm{mg} 17$ ( $0.50 \mathrm{mmol}, 1$ eq.), $332 \mathrm{mg}$ 1-bromodecane $(1.50 \mathrm{mmol}$, 3 eq.), $311 \mathrm{mg} \mathrm{K}_{2} \mathrm{CO}_{3}$ (2.25 mmol, 4.5 eq.), and $12 \mathrm{mg}$ $[\mathrm{RhCl}(\mathrm{cod})]_{2}(0.025 \mathrm{mmol}, 0.05$ eq. $)$ in $2 \mathrm{~cm}^{3}$ dry and degassed toluene. The reaction mixture was heated for $22 \mathrm{~h}$ at $160{ }^{\circ} \mathrm{C}$. The general work-up procedure $\mathrm{B}$ for $\mathrm{C}-\mathrm{H}$ activation reactions was followed using a gradient which varies the solvents from 0\% to 5\% EtOAc within 45 min. Drying under reduced pressure delivered 25 in $62 \%$ (126 mg) yield. TLC: $R_{\mathrm{f}}=0.79$ (LP/EtOAc 10:1); ${ }^{1} \mathrm{H}$ NMR $(400 \mathrm{MHz}$, $\left.\mathrm{CDCl}_{3}\right): \delta=0.87\left(\mathrm{t}, J=6.8 \mathrm{~Hz}, 3 \mathrm{H}, \mathrm{C}[12]-\mathrm{H}_{3}\right), 1.19-1.39$ $\left(\mathrm{m}, 16 \mathrm{H}, \mathrm{C}[7-11]-\mathrm{H}_{2}\right), 1.78-1.94\left(\mathrm{~m}, 2 \mathrm{H}, \mathrm{C}[3]-\mathrm{H}_{2}\right), 2.16$ $\left(\mathrm{s}, 3 \mathrm{H}, \mathrm{C}[7 \mathrm{a}]-\mathrm{H}_{3}\right), 4.47(\mathrm{~d}, J=7.0 \mathrm{~Hz}, 1 \mathrm{H}, \mathrm{N}-\mathrm{H}), 5.30$ $(\mathrm{q}, J=7.2 \mathrm{~Hz}, 1 \mathrm{H}, \mathrm{C}[2]-\mathrm{H}), 6.50(\mathrm{dd}, J=7.1,5.2 \mathrm{~Hz}$, $1 \mathrm{H}, \mathrm{C}[6 \mathrm{a}]-\mathrm{H}), 7.23(\mathrm{~d}, J=7.1 \mathrm{~Hz}, 1 \mathrm{H}, \mathrm{C}[4 \mathrm{a}]-\mathrm{H}), 7.48$ $(\mathrm{d}, J=8.1 \mathrm{~Hz}, 2 \mathrm{H}, \mathrm{C}[2 \mathrm{~b} ; 6 \mathrm{~b}]-\mathrm{H}), 7.55(\mathrm{~d}, J=8.1 \mathrm{~Hz}, 2 \mathrm{H}$, C[3b; 5b]-H), $7.91(\mathrm{dd}, J=5.1,1.7 \mathrm{~Hz}, 1 \mathrm{H}, \mathrm{C}[6 \mathrm{a}]-\mathrm{H}) \mathrm{ppm}$;
${ }^{13} \mathrm{C}$ NMR (101 MHz, $\mathrm{CDCl}_{3}$ ): $\delta=14.1$ (q, C[12]), 17.0 (q, $\mathrm{C}[7 \mathrm{a}]), 22.7$ (t, C[11]), $26.3(\mathrm{t}, \mathrm{C}[10]), 29.3$ (t, C[8]), 29.5 (t, $\mathrm{C}[6,7]), 29.6$ (t, C[5, 9]), 31.9 (t, C[4]), 37.6 (t, C[3]), 54.6 (d, C[2]), 113.0 (d, C[5a]), 122.9 (s, C[7b]), 125.3 (d, C[3b; 5b]), 126.8 (d, C[2b; 6b]), 128.7 (s, C[3a]), 129.1 (s, C[4b]), 137.8 (d, C[4a]), 145.0, (s, C[1b]), 148.8 (d, C[6a]), 155.5 (s, C[2a]) ppm; GC-MS: retention time: $8.52 \mathrm{~min}$; main fragments: $m / z(\%)=406\left(\mathrm{M}^{+}, 11\right), 279(34), 265(100), 159$ (8), 108 (64), 92 (30) 65 (11).

Acknowledgements Open access funding provided by TU Wien (TUW).

Open Access This article is distributed under the terms of the Creative Commons Attribution 4.0 International License (http://creativeco mmons.org/licenses/by/4.0/), which permits unrestricted use, distribution, and reproduction in any medium, provided you give appropriate credit to the original author(s) and the source, provide a link to the Creative Commons license, and indicate if changes were made.

\section{References}

1. Shang R, Ilies L, Nakamura E (2017) Chem Rev 117:9086

2. Xue X-S, Ji P, Zhou B, Cheng J-P (2017) Chem Rev 117:8622

3. Gensch T, Hopkinson MN, Glorius F, Wencel-Delord J (2016) Chem Soc Rev 45:2900

4. Ma W, Gandeepan P, Li J, Ackermann L (2017) Org Chem Front $4: 1435$

5. Chen Z, Wang B, Zhang J, Yu W, Liu Z, Zhang Y (2015) Org Chem Front 2:1107

6. Sambiagio C, Schönbauer D, Blieck R, Dao-Huy T, Pototschnig G, Schaaf P, Wiesinger T, Zia MF, Wencel-Delord J, Besset T, Maes BUW, Schnürch M (2018) Chem Soc Rev 47:6603

7. Dong Z, Ren Z, Thompson SJ, Xu Y, Dong G (2017) Chem Rev 117:9333

8. Spettel M, Pollice R, Schnürch M (2017) Org Lett 19:4287

9. Pollice R, Dastbaravardeh N, Marquise N, Mihovilovic MD, Schnürch M (2015) ACS Catal 5:587

10. Pollice R, Schnürch M (2015) J Org Chem 80:8268

11. Zhu R-Y, He J, Wang X-C, Yu J-Q (2014) J Am Chem Soc 136:13194

12. Gao K, Yoshikai N (2013) J Am Chem Soc 135:9279

13. Chen K, Shi B-F (2014) Angew Chem Int Ed 53:11950

14. Aihara Y, Chatani N (2013) J Am Chem Soc 135:5308

15. Song W, Lackner S, Ackermann L (2014) Angew Chem Int Ed 53:2477

16. Monks BM, Fruchey ER, Cook SP (2014) Angew Chem Int Ed 53:11065

17. Wu X, Zhao Y, Ge H (2014) J Am Chem Soc 136:1789

18. Jana CK, Grimme S, Studer A (2009) Chem Eur J 15:9078

19. Dastbaravardeh N, Schnürch M, Mihovilovic MD (2012) Org Lett $14: 1930$

20. Dastbaravardeh N, Kirchner K, Schnürch M, Mihovilovic MD (2013) J Org Chem 78:658

21. Schnürch M (2015) Arkivoc 212

22. Chatani N, Asaumi T, Yorimitsu S, Ikeda T, Kakiuchi F, Murai S (2001) J Am Chem Soc 123:10935 